\title{
Sabotaging the Peace: The Politics of Extremist Violence
}

\author{
Andrew Kydd; Barbara F. Walter
}

International Organization, Vol. 56, No. 2. (Spring, 2002), pp. 263-296.

Stable URL:

http://links.jstor.org/sici?sici=0020-8183\%28200221\%2956\%3A2\%3C263\%3ASTPTPO\%3E2.0.CO\%3B2-\%23

International Organization is currently published by The MIT Press.

Your use of the JSTOR archive indicates your acceptance of JSTOR's Terms and Conditions of Use, available at

http://www.jstor.org/about/terms.html. JSTOR's Terms and Conditions of Use provides, in part, that unless you have obtained prior permission, you may not download an entire issue of a journal or multiple copies of articles, and you may use content in the JSTOR archive only for your personal, non-commercial use.

Please contact the publisher regarding any further use of this work. Publisher contact information may be obtained at http://www.jstor.org/journals/mitpress.html.

Each copy of any part of a JSTOR transmission must contain the same copyright notice that appears on the screen or printed page of such transmission.

JSTOR is an independent not-for-profit organization dedicated to and preserving a digital archive of scholarly journals. For more information regarding JSTOR, please contact support@jstor.org. 


\section{Sabotaging the Peace: \\ The Politics of Extremist Violence}

Andrew Kydd and Barbara F. Walter

I asked him when, and why, he had decided to volunteer for martyrdom. "In the spring of 1993, I began to pester our military leaders to let me do an operation," he said. "It was around the time of the Oslo accords, and it was quiet, too quiet. I wanted to do an operation that would incite others to do the same. Finally, I was given the green light to leave Gaza for an operation inside Israel."

-Nasra Hassan

On Sunday 25 February 1996 a Palestinian student stepped onto a crowded bus in Jerusalem and detonated a bomb, killing twenty-six Israelis. One week later a second Palestinian detonated a bomb on a Jerusalem bus, killing eighteen Israelis. The following day a known Muslim extremist lay down on a busy street in Tel Aviv and blew himself up along with ten Israelis. These attacks were designed to undermine and halt what extremist groups viewed as the humiliating and misguided Palestinian-Israeli peace process, and within three months they had achieved this goal. On 26 May 1996 Israelis replaced Prime Minister Shimon Peres with the more hawkish Benjamin Netanyahu, and soon thereafter negotiations between Israel and the Palestinian Authority stalled. Although the bombings were clearly the work of a small band of Palestinian extremists, these extremists were able to convince a majority of Israeli citizens to walk away from a peace process most of them strongly supported.

This story illustrates two intriguing patterns in extremist violence. First, most extremist violence is not indiscriminate or irrational as many people have assumed. In fact, terrorist attacks in Northern Ireland and the Middle East over the last ten years show a clear and recurring pattern, where violence is timed to coincide with

We thank Gary Bass, Elisabeth Gerber, Barbara Koremenos, Gershon Shafir, Duncan Snidal, Jessica Stern, and participants of the Program on International Security and Politics at the University of Chicago, the Political Economy Seminar at the University of California, San Diego, and the Workshop in Political Economy at the University of California, Los Angeles. 
major events in a peace process. Some of the individuals who delivered these bombs, such as the failed bomber interviewed by Nasra Hassan, were quite conscious of the strategic logic of their actions. ${ }^{1}$ Although others may have been driven by their own irrational and idiosyncratic motives (such as a desire for revenge or eternal salvation), they appear to be playing a role in a campaign that seems quite strategic in its overall direction. Second, extremists are surprisingly successful in bringing down peace processes if they so desire. Between 1988 and 1998, fourteen peace agreements were signed between combatants engaged in civil war. If terrorist violence occurred during negotiations, just one in four treaties ( 25 percent) were put into effect. ${ }^{2}$ However, if terrorist violence did not occur, six out of ten treaties (60 percent) were implemented. Although extremists are known to espouse radical views and to represent only a small minority of citizens, they are surprisingly successful in their aims.

Events such as these pose two questions for students of conflict resolution. Why are extremists able to sabotage the peace process in some cases but not in others? Why does the public sometimes respond to such provocation and return to unpopular wars?

In what follows, we argue that extremists succeed in destroying a peace settlement if they are able to foster mistrust between more moderate groups that must implement the deal; they fail if the moderate groups retain an adequate level of mutual trust in each other's willingness to fulfill the deal. The purpose of extremist violence is not to achieve anything directly in a military sense, nor to signal that the extremist group opposes the peace treaty, which is already known. The purpose is to exacerbate doubts among those on the targeted side that the moderate opposition groups can be trusted to implement the peace deal and will not renege on it later.

The basic story goes like this: Whenever two sides negotiate a peace agreement, there is uncertainty about whether or not it is self-enforcing. Each side fears that though it may carry out its side of the bargain, the other side will not, catapulting it back to war on disadvantageous terms. Some Israelis, for example, feared that if Israel returned an additional 13 percent of the West Bank to the Palestinians as mandated by the Wye accord, the Palestinian Authority would relaunch its struggle from an improved territorial base.

Extremists understand that moderates on the other side of the table fear being taken advantage of and will look for signs that their former enemy will violate an agreement. They understand that targeting these moderates with violence will increase their fear and make them increasingly less likely to implement any terms. Thus terrorist bombs are designed to persuade a targeted group that the seemingly moderate opposition with whom it negotiated an agreement will not stop terrorism, and hence cannot be trusted to implement the deal. In fact, even if moderate leaders are willing to aggressively suppress their own terrorists, terrorists know that isolated

1. Nasra Hassan, An Arsenal of Believers, The New Yorker, 19 November 2001.

2. Data from the International Policy Institute for Counter-Terrorism database, the Interdisciplinary Center, Herzliya; and Walter 2002. 
violence might still convince the target to reject a deal. This is because the targeted group may not be able to readily observe the extent of the crackdown and must base its judgments primarily on whether terrorism occurs or not. Even an aggressive strategy of self-policing will not necessarily convince the targeted group to proceed with a settlement if a terrorist attack slips through. Extremist violence, therefore, plays on the uncertainty that exists between more moderate groups and can lead them to reject a peace settlement even if majorities on both sides initially favored the deal.

The key question is when will terrorist attacks drive the level of trust below the critical threshold required for cooperation. We present several findings that shed light on this question. One of the most interesting has to do with perceptions of the strength of the opposition moderate group. Terrorism may actually be more successful when moderates are perceived to be most capable of halting terrorism. This is because parties are also uncertain about whether the other side is capable of suppressing the extremists, that is, whether the moderates are weak or strong. In the Israeli-Palestinian case, Israelis were not sure that Yasir Arafat could suppress Hamas even if he tried. Intuition might suggest that terrorism would be more apt to derail peace accords if the opposition moderates are perceived to be weak. This does not appear to be the case. On the one hand, a belief that the opposition moderates are weak lowers the value of peace, and this in turn raises the minimum threshold of trust necessary for cooperation. This may make terrorism more likely to succeed. On the other hand, the weaker the moderates are perceived to be, the less of an impact a terrorist attack will have on the other side's trust, and the less likely such an attack is to succeed. This is because a terrorist attack provides little information on the trustworthiness of the moderates, since the moderates would have been unlikely to succeed in stopping the attack even if they had tried. Weak moderates cannot stop terrorism and therefore cannot be blamed for being untrustworthy in the aftermath of a terrorist attack. This effect may outweigh the first effect, so that on net the weaker the moderate opposition group, the less likely terrorism is to succeed in derailing a peace deal.

The article has two main sections. First, we present a game theoretic model that analyzes terrorist violence as a problem of trust between a moderate opposition group and a target government regarding carrying out a previously negotiated peace treaty. ${ }^{3}$ Second, we discuss the implications of the model in the context of the Israeli-Palestinian peace process from 1993 to 2001. The goal of the empirical work is not to "test" the model presented in the first section; one case is insufficient to test a general theory. ${ }^{4}$ Rather, our aim is to show that terrorist organizations often pursue their goals in rational and strategic ways, and to offer a plausible explanation for why a small group of radicals is sometimes able to convince a majority of peace-seeking individuals to return to conflicts they otherwise would prefer to

3. We are not the first to analyze terrorism from a rational choice perspective. For other excellent accounts, see Cetinyan and Stein 1997; and De Figueiredo and Weingast 1998.

4. See Bates et al. 1998 for an exploration of the interaction between case analysis and modeling. 
avoid. The strategic logic developed here, however, could apply to a wider variety of conflict-resolution contexts.

\section{The Model}

The model posits two sides to a dispute, where a side is the broadest possible grouping with similar preferences, such as Israelis versus Palestinians, Catholics versus Protestants in Ireland, and blacks versus whites in Rhodesia/Zimbabwe. One side is the "opposition" and is divided into moderates and extremists, actors M and E. The moderates are assumed to be the majority group on the opposition side, and they are the interlocutors with the other side. In the Israeli-Palestinian case, the Palestine Liberation Organization (PLO) and later the Palestinian Authority are the moderates. The extremists are a minority but are strong enough to conduct terrorist actions if they are not suppressed by the moderates and if they think it serves their interests. Hamas and Islamic Jihad are examples of extremists in the IsraeliPalestinian case. The other side represents the government $(\mathrm{G})$ or the side in power. ${ }^{5}$ The government side is being called upon to make some concession to the opposition in exchange for a cessation of hostilities. In the Israeli-Palestinian case this is the famous "land for peace" formula.

The model represents the implementation phase of an agreement that has already been reached between the opposition moderates and the government. ${ }^{6}$ The structure of the game is illustrated in Figure 1. The game has two stages. In the first stage, the moderates either attempt to suppress the extremists or decide not to. In the Israeli-Palestinian case, Arafat and the Palestinian Authority determine whether to clamp down on or accommodate Hamas. If the moderates attempt to suppress the extremists, they may or may not succeed, as will be detailed below. If the extremists are not effectively suppressed (because the moderates did not try or because they tried and failed), the extremists can then choose whether to launch a terrorist attack. ${ }^{7}$ The government side does not observe whether the moderates tried to suppress the extremists, only whether there has been a terrorist attack. We assume that the government cannot perfectly observe whether the moderates try to suppress the extremists for two reasons. First, the government's ability to monitor the other side is limited; the opposition has many secrets it wishes to keep from the government, and if the government were fully informed about the extremists, it would be able to

5. The asymmetry between the sides, reflected in the labels "government" and "opposition," corresponds to asymmetries present in many real world cases, most notably the Israeli-Palestinian case and the Irish case. However, we do not mean to imply that the roles are necessarily this distinct in all cases. In particular, the government side may contain extremist groups engaging in terrorism, and the labels "government" and "opposition" could just as easily be reversed.

6. The negotiating phase between the government and the moderate opposition is assumed to have already taken place and produced an agreement. We do not represent it here in order to focus on the enforcement problem in the simplest possible model. Of course, enforcement considerations will affect negotiations and vice versa, and we will discuss such effects in the context of the equilibria identified later. For a discussion of the interrelation between bargaining and enforcement, see Fearon 1998.

7. In focusing on "self-policing" by the opposition, the model resembles Fearon and Laitin 1996. However their model does not feature uncertainty about the motivations of the players and therefore does not model trust and mistrust, as ours does. 


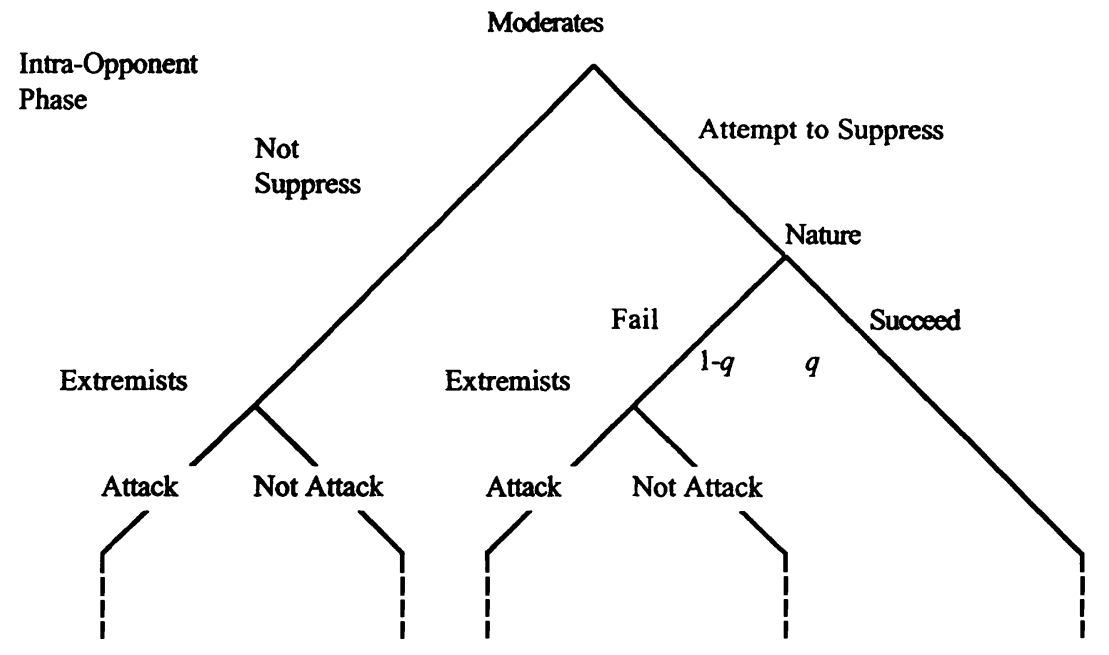

Trust Game Phase

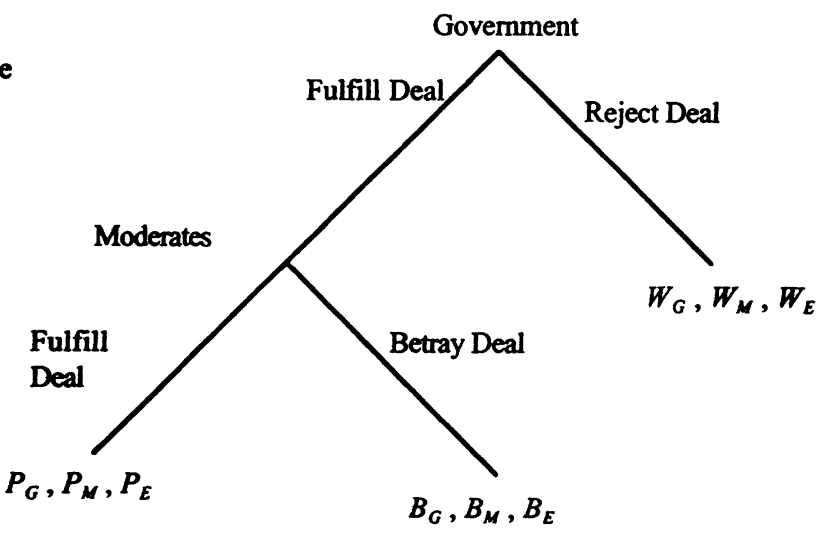

FIGURE 1. The structure of the game

stop terrorism itself. Second, international agents are also typically limited in their ability to monitor the moderates. The two sides will be reluctant to trust third parties with their most sensitive secrets, and third parties trusted by one side will generally be distrusted by the other. ${ }^{8}$ Thus we assume that the government cannot directly monitor the moderates' efforts to suppress the extremists.

8. While the difficulties of third-party monitoring are substantial enough to justify focusing on a model with no monitoring, especially as a first step in the modeling dialog, we do not claim that these 
TABLE 1. Game notation

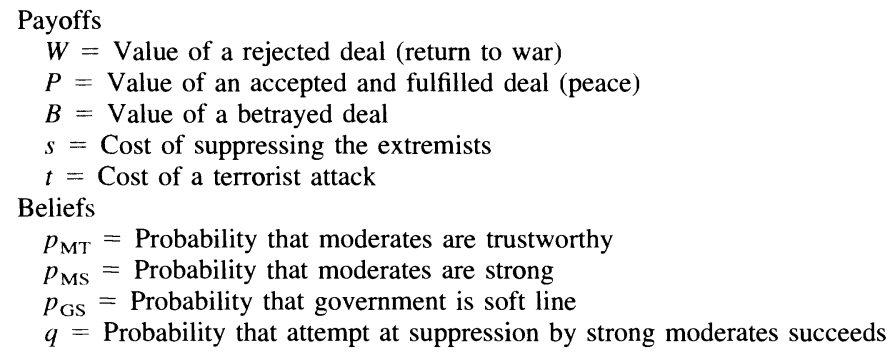

In the second phase, the government side plays a trust game with the opposition moderates. ${ }^{9}$ The government must decide whether to carry out the previously negotiated deal with the moderate opposition or reject it. In the Middle East case, the Israeli government would decide whether to withdraw from certain areas in the West Bank and Gaza as mandated by the Oslo accords or ignore the terms of the agreement and continue to occupy these areas. If the government side decides to reject the deal, perhaps in response to terrorist attacks, then the deal falls through and the two sides return to a state of conflict. If the government implements the deal, the opposing moderates have the final move: they can either betray the government and relaunch the struggle, or they can live up to the deal as negotiated.

The game has three outcomes: the government can reject the deal, the government can fulfill the deal and the opposing moderates can then choose to fulfill their side of the bargain as well, or the government can fulfill the deal and the opposing moderates can betray them by reneging. The rejected deal can be thought of as a return to war, and payoffs are denoted $W_{\mathrm{G}}, W_{\mathrm{M}}, W_{\mathrm{E}}$, for the government, opposition moderates, and opposition extremists, respectively. An accepted deal that is fulfilled by the moderates can be thought of as a successful conclusion of peace; thus the payoffs are denoted $P_{\mathrm{G}}, P_{\mathrm{M}}$, and $P_{\mathrm{E}}$. The payoffs for a deal the government fulfills and the opposition moderates betray are denoted $B_{\mathrm{G}}, B_{\mathrm{M}}$, and $B_{\mathrm{E}}$. In addition to these basic payoffs associated with the various outcomes, if the extremists launch a terrorist attack, this imposes costs on each player: $t_{\mathrm{G}}, t_{\mathrm{M}}$ and $t_{\mathrm{E}}$, and if the moderates try to suppress the extremists, this effort costs the moderates $s_{\mathrm{M}}$. The game notation is summarized in Table 1.

difficulties are insurmountable. Indeed, monitoring should be one of the core tasks in third-party efforts to assist in overcoming the problems we identify. We return to this issue in the conclusion.

9. For the origins of this model, see Coleman 1990. For subsequent applications, see Güth and Kliemt 1994; and Kydd 2000. 


\section{Uncertainty, Beliefs, and Payoffs}

In order for the model to reflect the endemic uncertainty involved in implementing peace deals, the game features two-sided incomplete information. There is uncertainty about three key issues: whether the opposition moderates will fulfill the peace deal, how capable the moderate opposition is of suppressing the extremists, and how committed the government is to peace.

The opposition moderates, therefore, are divided into four different types, based on whether they will fulfill the peace deal, and how capable they are of suppressing the extremists. "Trustworthy" moderates prefer a successfully implemented deal to betraying the government and returning to conflict, $P_{\mathrm{MT}}>B_{\mathrm{MT}}$, whereas "untrustworthy" moderates have the opposite preference, $B_{\mathrm{MU}}>P_{\mathrm{MU}}$. Thus trustworthy moderates will fulfill the peace deal if given the chance, while untrustworthy moderates will betray the government and return to conflict. The likelihood that the moderates are trustworthy is $p_{\mathrm{MT}}$ and the chance that they are untrustworthy is $p_{\mathrm{MU}}=1-p_{\mathrm{MT}}{ }^{10}{ }^{1}$ This prior belief represents the government's level of trust of the moderate opposition. In the case of Israel, the Israeli government's trust in Arafat and the Palestinian Authority is at least partially determined by their behavior in the past. The higher $p_{\mathrm{MT}}$ is, the more likely the government thinks the opposition moderates are trustworthy, and hence willing to fulfill the peace deal. The lower $p_{\mathrm{MT}}$ is, the more suspicious the government is that the opposition is untrustworthy and will betray them.

Moderates are also distinguished based on their ability to suppress terrorist violence. "Strong" moderates are able to actively suppress extremists within their ranks, whereas "weak" moderates are not. The degree of strength depends on the ability of moderates to suppress the extremists if they try and the costs they must expend in terms of money and popular support to contain these extremists. Formally, if the moderates are strong and attempt to suppress the extremists, they will succeed with a probability $q$, and fail with a probability $1-q$. This assumption that even strong moderates are not capable of eliminating terrorism with certainty reflects the reality that terrorist attacks are hard to block even under the best of circumstances. Weak moderates, by contrast, always fail in their attempt to suppress extremists (for them, $q=0$ ). The prior likelihood of facing a strong moderate is $p_{\mathrm{MS}}$, and the likelihood of facing a weak moderate is $p_{\mathrm{MW}}=1-p_{\mathrm{MS}}$. The two variables on which the moderates are distinguished produce four possible types. Figure 2 shows the four possible types of opposition moderate, and the likelihood of facing each one.

To incorporate uncertainty about the government, we posit two types of government, soft line (GS) and hard line $(\mathrm{GH})$ where there is a $p_{\mathrm{GS}}$ chance of a soft-line government and a $p_{\mathrm{GH}}=1-p_{\mathrm{GS}}$ chance of a hard-line government. The types are differentiated by their payoffs; the soft-line government's preferences are notated

10. The moves by Nature that set up the information structure and the associated information sets are omitted in Figure 1 for the sake of clarity. 
Preferences

\begin{tabular}{|c|c|c|}
\hline & Trustworthy & Untrustworthy \\
\hline Strong & $\begin{array}{l}\text { Trustworthy---strong } \\
p_{\mathrm{MT}} \times p_{\mathrm{MS}}\end{array}$ & $\begin{array}{l}\text { Untrustworthy---strong } \\
\left(1-p_{\mathrm{MT}}\right) \times p_{\mathrm{MS}}\end{array}$ \\
\hline Weak & $\begin{array}{l}\text { Trustworthy---weak } \\
p_{\mathrm{MT}} \times\left(1-p_{\mathrm{MS}}\right)\end{array}$ & $\begin{array}{l}\text { Untrustworthy---weak } \\
\left(1-p_{\mathrm{MT}}\right) \times\left(1-p_{\mathrm{MS}}\right)\end{array}$ \\
\hline
\end{tabular}

FIGURE 2. The four types of opposition moderates

$P_{\mathrm{GS}}, W_{\mathrm{GS}}$, and $B_{\mathrm{GS}}$ and the hard-line government's are $P_{\mathrm{GH}}, W_{\mathrm{GH}}$, and $B_{\mathrm{GH}}$. Both types of government have the same preference ordering, $P_{\mathrm{G}}>W_{\mathrm{G}}>B_{\mathrm{G}}$. That is, both types of government most prefer peace, but would prefer to return to conflict by rejecting the deal themselves rather than by being betrayed after they fulfill the deal. The driving consideration for the government in this comparison is that fulfilling the deal involves some concessions that strengthen the opposition side, such as the release of prisoners or territorial concessions. The two types of government differ in the strength of their preference for peace; a soft-line government has a stronger relative preference for peace than the hard-line government. That is, the soft-line government has a higher valuation for peace, $P_{\mathrm{GS}}>P_{\mathrm{GH}}$, a lower valuation for war, $W_{\mathrm{GS}}<W_{\mathrm{GH}}$, or higher valuation of the betrayal outcome, $B_{\mathrm{GS}}>B_{\mathrm{GH}}$, or some combination of the above. This implies that the soft-line government is willing to take greater risks for peace.

We introduce a further distinction in the value of peace for the government depending on whether it is facing strong or weak moderates. The idea here is that peace with strong moderates is more desirable to the government than peace with weak moderates, because strong moderates will be able to suppress future terrorist attacks, whereas weak moderates will not. As one Israeli academic put it, "if (Arafat) is incapable of controlling violence in his territory, what kind of partner is he? We have a problem with Arafat if willingly he does not control violence, but also if unwillingly he does not control it." ${ }^{11}$ The value of peace for the government with strong moderates is denoted $P_{\mathrm{G}}^{\mathrm{S}}$, and that with weak moderates is $P_{\mathrm{G}}^{\mathrm{W}}$ where $P_{\mathrm{G}}^{\mathrm{S}}$ $>P_{\mathrm{G}}^{\mathrm{W}}$. We assume that for both types of government, peace with strong moderates is preferred to a return to war, though peace with weak moderates may or may not be, that is: $P_{\mathrm{GS}}^{\mathrm{s}}>W_{\mathrm{GS}}$ and $P_{\mathrm{GH}}^{\mathrm{S}}>W_{\mathrm{GH}}$. 
For the extremists on the opposition side, we assume betrayal is preferred to peace, as it is for the untrustworthy moderates, so that $B_{\mathrm{E}}>P_{\mathrm{E}}$. However, we assume that returning to war now by convincing the government to reject the deal, $W_{\mathrm{E}}$, is the best outcome of all, so that $W_{\mathrm{E}}>B_{\mathrm{E}}>P_{\mathrm{E}}$. In other words, the extremists prefer to get the government to scupper the deal right away rather than have opposition moderates betray it later on. Two considerations underlie this preference ordering. First, the deal may involve concessions by the opposition side that the extremists find unacceptable. Such concessions may be largely symbolic, such as engaging in face-to-face meetings with the enemy and shaking hands in public ceremonies, but are too objectionable for the extremists to tolerate even as a ruse designed to deceive the enemy. Extremists may feel this opens the door for any number of additional compromises, all of which would be unacceptable. Extremists may also feel that getting the government to scupper the peace deal may give them an advantage in their own power struggle with the moderates for control of the opposition. If the moderates make concessions in peace negotiations that sell out cherished goals, and the enemy then rejects the deal, moderates can be portrayed as naive dupes. Thus, because the peace deal involves concessions that extremists find repugnant even in the short term, and because getting the government to kill the deal will aid their intra-opposition struggle for power, extremists always prefer to get the government side to reject the deal.

Finally, we assume that terrorism imposes costs on all players, the government side as well as the moderate and extremist sides. Terrorism is costly for the government side, since they are the targets of the violence. Terrorism is costly for the opposition moderates and terrorists because decision makers within both camps would prefer to obtain their ends without having to resort to violence.

\section{The Government's Decision and Their Level of Trust}

In any equilibrium, untrustworthy moderates will betray the deal and trustworthy moderates will fulfill it. This implies that the government's decision is based solely on the government's payoffs and its level of trust when it makes its decision. The government can either fulfill the peace deal, leaving itself open to the possibility that it will be exploited but also making a peaceful outcome possible, or it can reject the deal and return to war. For the soft-line government, the payoff for rejecting the deal is just $W_{\mathrm{GS}}$. The payoff for fulfilling the deal is a lottery over the two possible peaceful outcomes, with strong and weak moderates and the betrayal outcome as shown in the appendix. The government will find it worthwhile to fulfill the deal if the payoff for acceptance beats the war payoff, and this will be true if its level of trust exceeds a critical value denoted $p_{\mathrm{MT}}^{* \mathrm{~S}}$, for the soft-line government, and $p_{\mathrm{MT}}^{* \mathrm{H}}$, for the hard-line government.

If the level of trust is high enough-that is, if $p_{\mathrm{MT}}>p_{\mathrm{MT}}^{* \mathrm{~S}}$-the soft-line government will fulfill the deal, otherwise it will reject it. This critical value depends on the payoffs: increasing the values for peace, $P_{\mathrm{GS}}^{\mathrm{S}}$ and $P_{\mathrm{GS}}^{\mathrm{W}}$, decreasing the value 


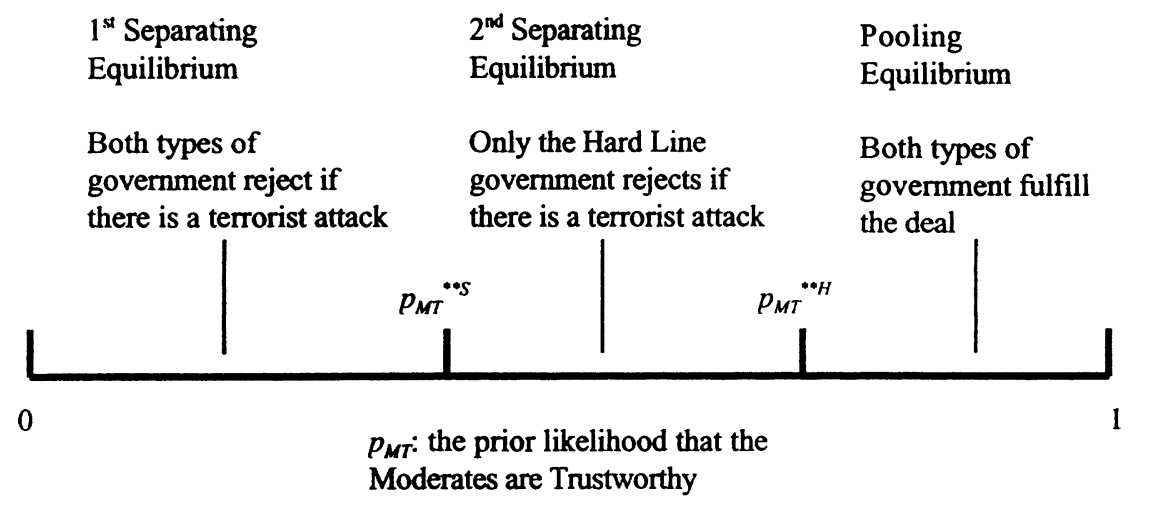

FIGURE 3. Equilibria in the game

for war, $\mathrm{W}_{\mathrm{GS}}$, and increasing the value for betrayal, $B_{\mathrm{GS}}$, will lower the critical value. These changes increase the relative value of peace for the government so that the government is willing to fulfill the deal for lower levels of trust. Increasing the government's confidence that it faces a strong moderate, $p_{\mathrm{MS}}$, has the same effect because it makes the better of the two peace outcomes, $P_{\mathrm{GS}}^{\mathrm{S}}$, more likely. Because the hard-line government has a higher value for war, lower value for peace, lower value for betrayal, or some combination of these factors, its critical value will be higher than that of the soft-line government, $p_{\mathrm{MT}}^{* \mathrm{H}}>p_{\mathrm{MT}}^{* \mathrm{~S}}$. This implies that there will be some intermediate levels of trust for which the soft-line government would be willing to fulfill the peace deal but the hard-line government would not, when $p_{\mathrm{MT}}^{* \mathrm{H}}>p_{\mathrm{MT}}>p_{\mathrm{MT}}^{* \mathrm{~S}}$.

\section{Equilibria in the Model}

We consider perfect Bayesian equilibria of the game. ${ }^{12}$ In any equilibrium, weak moderates will not attempt to suppress the extremists because they pay a cost for doing so and have no chance of success. Other strategy choices are contingent on the beliefs and equilibrium expectations. Equilibria in the model are illustrated in Figure 3 . The horizontal axis is the government's level of trust for the moderate opposition, $p_{\mathrm{MT}}$.

For high levels of trust, there is a "pooling" equilibrium in which the extremists do not attack and none of the four moderate opposition types makes an effort to suppress them. Both types of government then accept the deal regardless of whether an attack has occurred. In this zone, the government trusts the moderates so much 
that terrorist attacks are futile; even the hard-line government would not become distrustful enough to reject the deal.

For lower levels of trust, a terrorist attack would cause one or both types of government to reject the deal. Here we have separating equilibria: the strong trustworthy moderates attempt to suppress the extremists, the other three types do not try to do so, and the extremists attack if they get the chance. ${ }^{13}$ This enables a terrorist attack to act as a signaling device, since attacks are more likely to occur if the moderates are untrustworthy or weak.

In the separating equilibria, the government will update its beliefs depending on whether there was an attack. Given that only strong trustworthy opposition moderates attempt to suppress terrorism, the government may be certain that the moderates are trustworthy and strong if there is no attack. Hence, the government's posterior probability that the moderates are trustworthy, denoted with a prime, $p_{\mathrm{MT}}^{\prime}$, rises to 1 , as does the posterior belief that the moderates are strong, $p_{\mathrm{MS}}^{\prime}$. Knowing that the moderates will honor the deal, the government is happy to accept it.

But what if there is an attack? It is possible that strong, trustworthy moderates attempted but failed to suppress the extremists. But it is also possible that the moderates are either untrustworthy and did not want to suppress the extremists, or they are weak and hence incapable of suppressing them. The government's posterior probability estimates that the moderates are trustworthy and strong, given an attack, are shown in the appendix. These posterior beliefs are lower than the priors, that is $p_{\mathrm{MT}}^{\prime}<p_{\mathrm{MT}}$, and $p_{\mathrm{MS}}^{\prime}<p_{\mathrm{MS}}$. Therefore, the government becomes more suspicious of the moderates after an attack. The attack has the effect of making the government increasingly convinced that the moderates are untrustworthy and incapable of suppressing the extremists. Thus in this separating equilibrium, if there is no terrorist attack, the government becomes certain that they face a strong, trustworthy opposition moderate group and can fulfill the accords without any worries. If there is a terrorist attack, the government will become more suspicious of the opposition moderates, not certain that they are untrustworthy and weak, but tending more toward this belief than before the attack. This may or may not be sufficient to derail the peace accords.

By examining the formula for the posterior level of trust after a terrorist attack, $p_{\mathrm{MT}}^{\prime}$, we can discover the conditions under which an attack will be particularly damaging to trust and when it will be less so. What we find is that the greater the prior likelihood that the moderates are strong, $p_{\mathrm{MS}}$, the lower trust will be in the aftermath of a terrorist attack. Similarly, the greater the likelihood that strong moderates will succeed in suppressing the extremists if they try, $q$, the lower trust will be after an attack.

These results make intuitive sense. If moderates are viewed as strong and able to suppress terrorism, their failure to do so will be more surprising and more informative than if they are viewed as weak and unable to suppress terrorism,

13. In the appendix we discuss an alternative separating equilibrium in which both untrustworthy and trustworthy strong moderates attempt to suppress. 
though mutual trust will decline in both cases. In the extreme case, if the moderates are believed with certainty to be weak, $p_{\mathrm{MS}}=0$, then the posterior level of trust after an attack will equal the prior, and no decline in trust will take place. Conversely, if the moderates are believed with certainty to be strong and capable of suppressing the extremists if they try - that is, if $p_{\mathrm{MS}}=1$ and $q=1$-then the posterior belief will be zero after an attack, and there will be total loss of trust.

A similar result holds for the posterior belief that the moderates are strong, $p_{\mathrm{MS}}^{\prime}$. In the wake of a terrorist attack, the greater the prior belief that the moderates are trustworthy, the lower the posterior belief that they are strong. The lower the belief that they are trustworthy, the less decline in the belief that they are strong. This again makes intuitive sense: if the moderates are highly trusted, a terrorist attack will be surprising and provide considerable information that they are likely to be weak. If the moderates are hardly trusted at all, a terrorist attack will not be as surprising nor provide as much information that they are weak.

In the separating equilibria, the government will fulfill the deal if its prior level of trust exceeds a critical value, denoted $p_{\mathrm{MT}}^{* * \mathrm{~S}}$ for the soft-line government and $p_{\mathrm{MT}}^{* * \mathrm{H}}$ for the hard-line government. If the prior level of trust exceeds this critical value, for the soft-line government if $p_{\mathrm{MT}}>p_{\mathrm{MT}}^{* * \mathrm{~S}}$, then even after a terrorist attack the government will be willing to fulfill the deal. If the prior level of trust falls below this level, the extremist attack will make the government too mistrustful to fulfill the deal. These critical values are illustrated in Figure 3 and form the boundaries between the equilibria.

Two things are important to note about these critical values. First, they are higher than those previously mentioned, that is, $p_{\mathrm{MT}}^{* * \mathrm{~S}}>p_{\mathrm{MT}}^{* \mathrm{~S}}$ and $p_{\mathrm{MT}}^{* * \mathrm{H}}>p_{\mathrm{MT}}^{* \mathrm{H}}$. The gap between the new and the old critical values is precisely the loss of trust that has occurred due to the terrorist attack; that is, if the government starts the game with a level of trust equal to $p_{\mathrm{MT}}^{* * \mathrm{~S}}$, the terrorist attack will reduce its level of trust to $p_{\mathrm{MT}}^{* \mathrm{~S}}$, leaving it indifferent between either fulfilling the deal or rejecting it. The more trust is lost as a result of the terrorist attack, the greater $p_{\mathrm{MT}}^{* * \mathrm{~S}}$ will be in relation to $p_{\mathrm{MT}}^{* \mathrm{~S}}$.

Second, the critical value for the hard-line government will be higher than that for the soft-line government, $p_{\mathrm{MT}}^{* * \mathrm{H}}>p_{\mathrm{MT}}^{* * \mathrm{~S}}$. This produces two versions of the separating equilibria, as illustrated in Figure 3. In the first, both types of government, hard line and soft line, are suspicious enough to reject a deal if a terrorist attack occurs. In this case, the prior belief falls below the cutoff level for the soft-line government, $p_{\mathrm{MT}}<$ $p_{\mathrm{MT}}^{* * \mathrm{~S}}$. Given that the soft-line type is suspicious enough after an attack to reject the deal, the hard-line type will be as well. In this separating equilibrium, a successful terrorist attack will derail the peace accords with certainty. Note that this first separating equilibrium occurs to the left-hand side of Figure 3, where $p_{\mathrm{MT}}$ is low, and the government is relatively suspicious of the opposition moderates. When the government starts off being relatively fearful that the opposition is untrustworthy, a terrorist attack will derail the peace accords for sure.

In the second separating equilibrium, the soft-line government will not reject the peace deal even in the face of a terrorist attack. Its commitment to peace is strong enough that sticking to the deal makes sense, even though the terrorism has 
increased its level of suspicion. However, the hard-line government will still decide to reject the deal if there is a terrorist attack. Here, the prior beliefs about the opposition moderates fall between the two critical values for the government types, $p_{\mathrm{MT}}^{* * \mathrm{~S}}<p_{\mathrm{MT}}<p_{\mathrm{MT}}^{* * \mathrm{H}}$. Thus in the second separating equilibrium, it is possible for a terrorist attack to occur yet not derail the peace deal. This second separating equilibrium takes place to the right of the first one: $p_{\mathrm{MT}}$ is higher, so the government has a higher level of trust. The higher prior level of trust allows the soft-line government to fulfill the accords in spite of the terrorist attack.

The separating equilibria, then, capture the possibility that terrorism can be used to destroy a peace settlement, and that attempting to suppress terrorism can be used as a signal that a moderate opposition group is strong and committed to the peace process. What the separating equilibria show us is that terrorism can indeed wreck peace accords by serving as a signal of the intentions of the moderate opposition group. Because the trustworthy strong moderates are expected to make the attempt to suppress the extremists, any terrorist attack raises the government's estimate that it faces an untrustworthy or weak moderate group that will betray the peace accord in the end. This shift in beliefs may convince the government not to trust the moderates and hence not to accept the peace deal, returning the groups to a state of war. Terrorism sometimes succeeds, therefore, because of the message it sends not about the terrorists but about the moderates, not the terrorists.

\section{Implications of the Model}

We sum up the implications of the model in four hypotheses on when terrorism will be employed to disrupt peace agreements and when it will succeed. The first hypothesis contrasts the pooling equilibrium at high levels of trust where extremists do not attack with the separating equilibria for lower levels of trust where extremists do attack.

HYPOTHESIS 1: The higher the prior level of trust between opposing sides, the lower the likelihood that extremists will attack in an attempt to disrupt peace agreements.

In some cases, because of personal rapport between leaders or referenda demonstrating widespread support for peace, the level of trust is high enough that terrorism would not disrupt it sufficiently to cause a return to conflict. In such cases, terrorism is unlikely to be attempted. A case in point is the current situation in Northern Ireland, where terrorist attacks have virtually ceased.

The second hypothesis contrasts the first and second separating equilibria, and the hard-line and soft-line governments.

HYPOTHESIS 2: Soft-line governments are more likely to cooperate in spite of terrorism than hard-line governments. Anything that increases the government's value for peace, lowers its value for war, and increases its payoff if betrayed will lower its critical threshold of trust, making cooperation easier in the face of terrorist attacks. 
Next we address when attacks will be especially effective in lowering the level of trust and hence more likely to succeed in disrupting the peace accords. Hypotheses $3 \mathrm{a}$ and $3 \mathrm{~b}$ deal with the relationship between perceptions of moderates' strength and the effects of terrorist attacks.

HYPOTHESIS 3a: The weaker the government believes opposition moderates to be, the lower the value it places on peace and the higher the minimum threshold of trust necessary for cooperation.

HYPOTHESIS 3b: The weaker the government believes opposition moderates to be, the less effect a terrorist attack will have in lowering its level of trust.

Hypothesis 3a reflects the fact that the government is more likely to receive the less attractive of the two peace payoffs, $P_{\mathrm{GS}}^{\mathrm{W}}$ (for the soft-line government), if the opposition moderates are weak. This raises the minimum trust threshold, $p_{\mathrm{MT}}^{* * \mathrm{~S}}$, and makes cooperation more difficult to achieve. This would seem to make terrorism more effective in the face of weak moderates, as intuition might suggest.

Hypothesis $3 b$ counteracts this effect, however. According to this hypothesis, the weaker the moderates, the less of an impact any terrorist attack will have on the level of trust. This is the case because weak moderates are less capable of suppressing attacks and so cannot be blamed if attacks occur. If the moderates could not have prevented attacks even had they tried, the fact that attacks happened cannot be used as evidence that they did not try.

Thus, while weakness on the part of the moderates raises the minimum threshold of trust necessary for cooperation, it also mitigates the decline in the level of trust that occurs as a result of terrorist attacks. Which effect dominates depends on the specific values of the parameters. If the government prefers peace with weak moderates rather than going back to war, then the second effect will likely dominate, because the government's value for peace will be high even with weak moderates. If the cost of terrorism is very high, so that peace with weak moderates is unappealing, then the first effect may dominate. In the Israeli-Palestinian case, as we will discuss, we argue that the second effect dominated. Arafat's weakness actually saved the peace process in the early 1990s by shielding him from accusations of untrustworthiness in the wake of early terrorist attacks, and his more recent perceived strength has significantly lowered Israel's trust by convincing Israel that Arafat could stop the renewal of the intifada but has chosen not to.

Finally, the fourth hypothesis addresses the effect of terrorist attacks on the government's belief that the moderate opposition is strong.

HYPOTHESIS 4: The more the government trusts the opposition, the more an attack will convince the government of the opposition's weakness. The less the government trusts the opposition, the less effect an attack will have on the government's beliefs about the moderates' capabilities. 
This hypothesis is the flip side of hypothesis $3 \mathrm{~b}$. Just as weakness provides an excuse for not suppressing the extremists, so does untrustworthiness. If the opposition moderates are untrustworthy, a terrorist attack will convey no information about whether they are capable of preventing attacks, because they would not have tried to prevent the attack in the first place. Trusted opposition moderates, however, will look weak if they fail to prevent terrorism.

\section{Welfare Implications}

A final set of implications of the model is worth considering. Terrorism imposes a direct cost on all sides in the model. For the government side, the main cost is the loss of life, the grief borne by survivors, and the fear it instills in the population. Even for the moderates and extremists on the opposition side, terrorism often claims lives - of the suicide bombers themselves, of innocent bystanders of their own group, and of Palestinians killed in retaliatory attacks by Israel. It might seem, therefore, that terrorism is welfare diminishing for all the players in the game. However, the indirect effects of terrorism may counterbalance this to some extent, at least for some players.

To assess the welfare implications of terrorism we need to compare a world in which terrorism is impossible (because of a lack of extremist groups, for instance) with one where it is possible. In other words, we need to compare the game as it is, with extremists who may attack if not suppressed, with an alternative version in which the extremists are not present and the government and moderates face each other with no third-party interference. It might seem simpler to ask whether terrorist attacks make the parties better or worse off in the game as it is. One way to do this would be to compare equilibria in which terrorism occurs and those in which it does not. However, to compare the pooling equilibrium in which the extremists do not attack with the separating equilibria in which they do is to compare two different regions of the parameter space, the high and low trust regions. In assessing the welfare effects of terrorism we need to hold everything else constant, especially the level of trust. Another way would be to ask, for a given level of trust and in a specific separating equilibrium, whether the parties are better off ex post if a terrorist attack does or does not take place. This strategy is also inadequate, because it is the possibility of terrorist attacks that gives their absence a special significance in the model. In the model as it is, the welfare effect of no terrorism is not simply the lack of the direct costs of terrorism but the beliefs that it generates about the moderate's type. Once again, beliefs are not being held constant in the comparison. ${ }^{14}$ Thus, the

14. Note this comparison would also mean that the welfare effect of terrorism would depend on whether it occurred or not; that is, a government that had seen no terrorist attack and had hence become optimistic about the trustworthiness of the moderates would view terrorism as doubly bad because of its direct costs and, from the government's perspective, the erroneous mistrust it would cause. If an attack were to occur, however, the government would regard it as especially good because had it not occurred, the government would have had unduly naïve beliefs. Thus a better comparison is the ex ante one made above. 
appropriate comparison is between a world in which terrorism is possible, the model as presented, and a world without extremists.

Terrorism is welfare-improving, on balance, for the extremists. Extremists could choose to make the world with terrorism resemble that without simply by not attacking. If they do choose to attack, it must be because this improves their welfare. For the moderate opposition, the possibility of terrorism has three negative effects and one positive. First, terrorism imposes direct costs: the loss of life and potential sanctions from the outside world. Second, successful terrorism makes the government side less likely to fulfill the peace deal that the moderates would like them to fulfill. Third, if the moderates make an effort to stop terrorism, they pay a political cost. Set against these considerations is the reassuring effect of successfully stopping terrorism. In the separating equilibria, if the moderates prevent an attack, this reassures the government and it fulfills the deal, which at least one type would not have done if an attack had occurred.

But which effect dominates and under what conditions? If trust is high, $p_{\mathrm{MT}}>$ $p_{\mathrm{MT}}^{* \mathrm{H}}$, then both types of government would have fulfilled the deal even if terrorism were impossible, so terrorism makes the moderates worse off. For medium trust, if $p_{\mathrm{MT}}^{* \mathrm{~S}}<p_{\mathrm{MT}}<p_{\mathrm{MT}}^{* \mathrm{H}}$, then the soft-line government would have fulfilled the deal but the hard-line government would not have. This means that in the world with terrorism the moderates have an opportunity to reassure hard-line governments and convince them to fulfill the deal, which they otherwise would not have done. Similarly, for low trust, if $p_{\mathrm{MT}}^{* \mathrm{~S}}>p_{\mathrm{MT}}$, then neither type of government would fulfill the deal absent reassurance, so terrorism offers an even greater potential benefit to moderates. In these last two cases, however, the precise balance between the positive and negative effects must be calculated to determine whether it is welfare improving on net.

For the government side, terrorism is costly and detracts from its welfare but also serves an important informational role. In the world without terrorism, the government has to take its chances on peace with the moderates based on its prior beliefs about their trustworthiness. With terrorism, the government gets additional information about the moderates: if an attack occurs, it says moderates are more likely to be untrustworthy and weak; if an attack does not occur, it says they are likely to be trustworthy and strong. This information may counterbalance the raw costs of terrorism, making the government better off on net but only if the attack causes the government to change its strategy from what it would have been in the no-terrorism world. For instance, for the soft-line government, with low trust, where $p_{\mathrm{MT}}<p_{\mathrm{MT}}^{* \mathrm{~S}}$, in a no-terrorism world the government would have rejected the deal, but in the world with terrorism, the government may fulfill it, leading to peace, if there is no attack. Terrorism may be welfare-improving in this case. For medium trust, if $p_{\mathrm{MT}}^{* \mathrm{~S}}$ $<p_{\mathrm{MT}}<p_{\mathrm{MT}}^{* * \mathrm{~S}}$, then in the no-terrorism world the government will fulfill the deal, but in the world with terrorism they will not fulfill the deal if there is a terrorist attack, so again terrorism can be welfare-improving. For high trust, $p_{\mathrm{MT}}>p_{\mathrm{MT}}^{* * \mathrm{~S}}$, the government would fulfill the deal whether or not terrorism actually occurs, so the world in which terrorism is possible is unambiguously worse. Similar relations hold 
for the hard-line government, though interestingly, when trust levels are very high, where $p_{\mathrm{MT}}>p_{\mathrm{MT}}^{* * \mathrm{H}}$, there is no difference between the world with terrorism and that without it because extremists do not attack if they have the chance.

For the moderates and the government, therefore, the possibility of terrorism, in spite of its direct costs, may actually be welfare improving under some conditions. For the moderates, the threat of terrorism allows them to reassure the government by preventing attacks, and for the government it provides additional information on the preferences of the moderates. It is important to emphasize, however, that these information effects on welfare may be swamped by the direct costs of terrorism. We are certainly not arguing that the Middle East is a better place because of the violence perpetrated by extremist groups, only that the possibility of violence has informational side effects that mitigate some of its costs.

\section{The Palestinian-Israeli Peace Process}

In the following section we look more closely at the Palestinian-Israeli peace process from 1993-2001. ${ }^{15} \mathrm{We}$ do this for three reasons. First, as early as 1991 majorities on both sides supported a land-for-peace deal, and this information was known to Palestinian and Israeli leaders involved in ongoing negotiations, making the failure of peace in this case particularly puzzling. ${ }^{16}$ Second, both camps included extremist factions that objected to a deal and used terrorism to try to prevent it. This allows us to observe how such factions can sometimes undermine otherwise popular negotiations. Third, these extremists failed in some cases and succeeded in others; bus bombs, hand grenades, and suicide attacks failed to break down the peace process from 1993 to 1996, and again in 1998, but succeeded from 1996 to 1998 and again in 2000-2001. Thus, the case features sub-cases that exhibit variation on the dependent variable.

We are especially interested in answering two sets of questions. First, did Hamas behave strategically in the sense our model predicts? ${ }^{17}$ If our theory is valid, Hamas's violent attacks should coincide with the ratification and implementation of individual peace accords; these are opportunities to prevent anticipated cooperation by increasing mistrust. Similarly, Hamas should also step up its attacks prior to Israeli elections in which Labor is the incumbent party in an effort to persuade

15. Negotiations between Israel and the Palestinians were only one of a series of bilateral negotiations between Israel and its Arab neighbors that comprise what is often loosely referred to as the "Middle East peace process." We have chosen to concentrate on the Palestinian-Israeli relationship because it is the core of the conflict between Arabs and Israelis and because most of the terrorism in the region is directed at Israel by Palestinian extremists.

16. At the signing of the Oslo I peace accord in September 1993, a poll showed that nearly two-thirds of Israelis and Palestinians supported the agreement. See Makovsky 1996.

17. Although we look only at Hamas for simplicity's sake, violence by the Islamic Jihad follows the same pattern. 
voters to install the less cooperative and less trusting hard-line Likud party. Successfully doing so is another means to prevent future cooperation.

Second, do the hypotheses from the model shed light on the Israeli reaction to terrorist attacks? If our theory is valid, terrorism should be most likely to succeed under Likud governments and when Arafat's power to suppress terrorism is perceived to be high. Moreover, Labor governments should be more likely than Likud governments to interpret terrorism as a sign of weakness rather than untrustworthiness and proceed with cooperation despite ongoing attacks.

What we will see is that Hamas acted quite strategically from 1993 to 2001, timing its violence to coincide either with the signing of a peace treaty or with elections in which soft-line administrations could be unseated. We will see that terrorism was especially effective after Arafat's 1996 electoral victory, which served to inform Israelis of Arafat's true strength within the Palestinian community. And as predicted, we find that Labor governments were more ready to cooperate in the face of terrorism than hard-line Likud governments.

\section{Periods of Intense Terrorist Activity}

As Figure 4 reveals, Hamas's attacks against Israel have not been random. From 1993 to 2001, Hamas concentrated its violence around six major events: (1) the September 1993 signing of the Oslo I peace accord, (2) the May 1994 signing of the Cairo agreement, (3) the October 1994 signing of a peace treaty between Israel and Jordan, (4) the 1996 Palestinian and Israeli elections, (5) the October 1998 signing of the Wye agreement, and (6) the February 2001 Israeli elections.

Two of these attacks succeeded in convincing the Israeli government to suspend negotiations with the Palestinians. Hamas's sustained campaign of violence against Israel from February to April 1996 helped install Benjamin Netanyahu's Likud government in power, and meaningful negotiations with Arafat ended soon thereafter. And a series of Hamas attacks from December 2000 onward helped remove Labor prime minister Ehud Barak from power in favor of the more hawkish Ariel Sharon, who proceeded to cut off talks with Arafat. Four other attacks, including those surrounding the signing of the 1993 Oslo accord, the 1994 Cairo agreement, the 1994 Israel-Jordan agreement, and the 1998 Wye accord, failed to have the desired effect.

We now briefly examine each of these events, paying particular attention to the timing of the attacks and the ways in which violence affected Israeli perceptions of Arafat and the Palestinian Authority and their commitment to the peace process.

October-November 1993. Hamas launched its first series of attacks on Israel on 4 October 1993, three weeks after Israeli prime minister Yitzhak Rabin and Yasir 


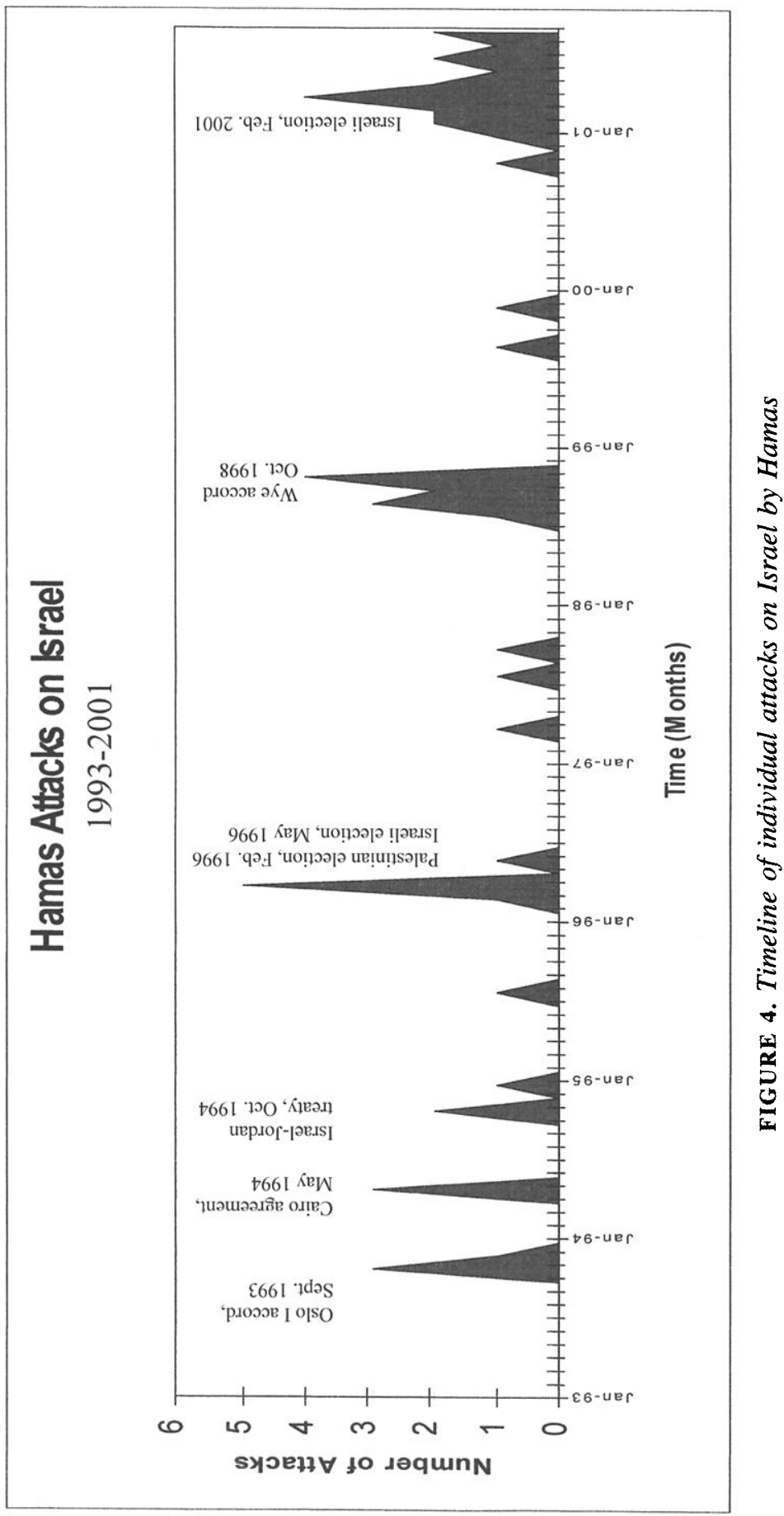


Arafat signed their first peace accord. ${ }^{18}$ The secret negotiations and the signed settlement caught Hamas off guard and only after the accord was made public did Hamas began its campaign to derail the peace process. In the future, Hamas would not wait until an agreement was signed with Israel to launch its attacks and would target its violence for the weeks and months preceding the final ratification of an accord.

From 4 October to 7 November, Hamas detonated four bombs, killing three Israelis and injuring twenty-nine others. The violence had no effect on the peace process. Arafat and Rabin continued to meet, and both sides began implementing the accord soon after it was signed. Two factors appear to explain this. First, Rabin's soft-line Labor party placed a high value on peace and was inclined to sustain the peace process even in the face of terrorist attacks. By 1992 the intifada and Israel's inability to suppress it had convinced Rabin and a majority of Israelis that they could not hold the occupied territories indefinitely. A land-for-peace deal would have to be made and a deal with the more moderate and secular PLO with Arafat as head was preferable to one with a fundamentalist Muslim group that might reign over the Palestinians in the future. As one Israeli official explained, "Israelis wanted to get out of Gaza so much, they were willing to accept Arafat as long as he agreed to end the state of war and amend the [Palestine National Council] Charter."19 Thus, in accordance with hypothesis 2, Israel's value for peace was high at this time, lowering the level of trust necessary for cooperation to occur in spite of terrorism.

Second, although Arafat had promised that the PLO would try to prevent violence, most Israelis did not believe Arafat had the ability to suppress all terrorist activity even if he tried. A poll by the Guttman Institute immediately before the signing of the Oslo accord found that "75 percent of Israelis expected violence to increase as a result of the accord, even though most of them supported [the accord]." 20 And Shimon Peres, Israel's minister of defense at the time, was fond of saying that "although Israel does not expect the [PLO] to produce 100 percent success, it would like to see 100 percent effort." 21 Many Israelis seemed to understand that Arafat was in a difficult position. ${ }^{22}$ If Arafat clamped down too harshly on Hamas, he risked chasing the Palestinians into the arms of more militant groups and eroding the PLO's support base. In addition, Israelis seemed to

18. The Oslo I accord, as it was called, had obtained concessions from both sides. In it, the Israeli government promised to give the Palestinians control of the Gaza Strip and the West Bank city of Jericho and withdraw its troops from those areas within four months. Within nine months, a Palestinian Council would be elected to govern and police the West Bank and Gaza for a five-year interim period. In return, Yasir Arafat and the PLO agreed to stop terrorism and amend a clause in the Palestinian National Covenant that called for the destruction of Israel. The agreement also called for additional negotiations within two years on control over Jerusalem and the status of 120,000 Jewish settlers in the occupied territories.

19. Makovsky 1996, 62.

20. Peter Ford, Israelis Shaken by Violence but Still Back Rabin's Deal, The Christian Science Monitor, 16 November 1993, 6.

21. Makovsky 1996, 150.

22. Mishal and Sela 2000. 
recognize that Arafat did not yet control the areas from which Hamas operated and could not, therefore, be expected to keep violence fully in check. The fact that Arafat was willing to arrest some Hamas soldiers seemed to satisfy Israelis, at least for the time being. Thus in accordance with hypothesis $3 b$, terrorist attacks had less of an impact on Israel's level of trust at this point in the peace process because Arafat was viewed as likely to be weak in his ability to police Hamas.

April 1994. Hamas launched its second series of attacks in April 1994, one month before Rabin and Arafat signed the Cairo agreement of May 1994. ${ }^{23}$ This second accord outlined the terms by which the PLO would take charge of the Gaza Strip and Jericho and promised that within twenty-four hours one thousand Palestinian policemen would replace departing Israeli troops in those areas.

Once again, Hamas's attack failed to halt the peace process. Two factors help explain this. Hamas continued to face an Israeli public pessimistic about the PLO's ability to end the violence. By 1994, only 35 percent of Israelis believed that the PLO could control terrorism even after taking over Gaza and Jericho. ${ }^{24}$ As hypothesis $3 b$ indicates, the less confidence there is in the opposition's ability to suppress the extremists, the smaller the decline in trust after a terrorist incident. This second series of terrorist attacks, therefore, served only to confirm what Israelis already believed: Arafat and the PLO would have great difficulty preventing all violence from striking Israel. It did not yet seriously undermine their beliefs about Arafat's willingness to do so.

Hamas had also chosen to direct its attacks against hard-line settlers living in the occupied territories, believing that pressure from this group of Israelis would force Rabin to reject the accords. This strategy, however, left the majority of Israeli citizens and most of Rabin's supporters unaffected by the costs of violence. ${ }^{25}$ If Hamas wished to shift public opinion and pressure Rabin into abandoning the peace process, it would have to target attacks at Jerusalem and Tel Aviv where most Israelis and most of Rabin's supporters lived.

October 1994. Hamas's third cluster of attacks, two weeks prior to the signing of the Israeli-Jordan peace treaty of October 1994, also failed to destroy the peace process. ${ }^{26}$ Once again, Israeli beliefs about Arafat's relative strength were at play. Although the PLO was to have taken administrative control of the West Bank and the Gaza strip immediately following the signing of the May 1994 Cairo agreement, the organization still did not have full control over most major Palestinian population centers by December 1994. The majority of Israelis, therefore, did not expect

23. From 6 to 16 April, Hamas detonated three bombs in Israel, killing fourteen and injuring ninety.

24. Arian 1995, 107.

25. Sixty percent of Israelis continued to support negotiations with the PLO at this point in the peace process. Arian 1995, 107.

26. Jerusalem and Tel Aviv were now targeted. On 9 October, Islamic terrorists fired automatic weapons in Jerusalem's Nahalat Shiva'a business district, killing two and injuring fourteen, and on 19 October a suicide bomber entered a crowded bus in Tel Aviv, killing twenty-two and wounding forty-six. 
Arafat to be able to prevent all terrorist attacks launched from these areas from occurring. As one senior U.S. official pointed out, Israelis realized that Arafat "with his undermanned, ill-trained, and poorly equipped police forces" could not wipe out the terrorism that the Israeli police and army had been unable to stop for decades. ${ }^{27}$ Additionally, Arafat's political support among the Palestinians was declining, and the Israeli government knew this. A poll conducted by the Center for Palestine Research and Studies in the West Bank town of Nablus in November 1994 found for the first time that Arafat did not have the support of the majority of Palestinians. ${ }^{28}$ Not only did Arafat not have full control over Palestinian activity, but his power within the Palestinian community was declining. A weak Arafat appeared to be getting weaker. It was expected, therefore, that some terrorist violence would get through.

Rabin and his soft-line Labor party also remained in control of the government, and their value for peace with the Palestinians continued to exceed the costs Israel paid in terrorist attacks. According to one long-time observer, "Rabin had long regarded Palestinian terrorism as a second-tier nuisance that posed no threat to Israel's existence and at worst inflicted suffering upon individual Israelis." ${ }^{29}$ For Rabin, even peace with weak moderates was better than renewed conflict with the Palestinians. In this case $P_{\mathrm{GS}}^{\mathrm{W}}>W_{\mathrm{GS}}$, making the government willing to overlook terrorist attacks and fulfill the peace deal even as it became convinced that Arafat and the Palestinian Authority's support appeared fragile.

March 1996. After three failed attempts to destabilize the peace process, Hamas significantly limited its attacks on Israel. Hamas detonated only two bombs from October 1994 to February 1996 and then chose to halt all terrorist activity after July 1995-the longest period of inactivity since attacks began in October 1993. This fits the first and fourth predictions made by the model. As long as a trusting Rabin remained in power and as long as Israelis perceived Arafat and the Palestinian Authority to be weak, Hamas had little incentive to launch additional attacks. Rabin appeared to have a sufficiently high level of trust in Arafat to make additional violence ineffective.

This situation changed dramatically on 20 January 1996 when the Palestinians held their first-ever election. Not only did Arafat win a landslide 88 percent of the vote, but the largest turn-out of Palestinian voters came from Gaza, Hamas's home base. ${ }^{30}$ Arafat's victory, especially among Palestinians living in Gaza, made it clear

27. Norman Kempster and Michael Parks, Arafat Pledges to Fight Terrorism Against Israelis, Los Angeles Times, 8 December 1994, A8.

28. Mark August, Shifting Sands and Arafat's Popularity, The Tampa Tribune, 28 November 1994, 4.

29. Makovsky 1996, 111 .

30. Kass and O'Neil 1997, 259. 
to Israel that Arafat was in fact quite strong and could pursue Hamas more aggressively without fear of losing legitimacy or popular support. ${ }^{31}$

Hamas renewed its attacks on Israel soon after the Palestinian election. This is in line with hypothesis $3 b$, which states that extremist violence will be more effective in lowering the government's level of trust when the government believes opposition moderates to be strong and thus capable of suppressing the extremists. On 25 February 1996 Hamas initiated its most sustained offensive against Israel since its inception, killing 102 people and injuring more than 80 others in less than three weeks. ${ }^{32}$ This time Hamas's attacks succeeded. From February to May 1996, public support in Israel for the peace process declined by its greatest percentage. ${ }^{33}$ This dramatic shift in public opinion led directly to the Labor government's defeat in the May 1996 elections, opening the door for the more hard-line Likud government of Benjamin Netanyahu. Three single suicide bombs detonated over the next two years provided Netanyahu with reasons to delay the implementation of previously agreedupon terms and bring the peace process to a halt.

Why did Hamas finally succeed? First, the January 1996 Palestinian vote gave Arafat the political mandate necessary to take strong action against Hamas and raised Israeli expectations that terrorism would decline. The fact that violence increased in both number and intensity in the months following this election signaled to the Israeli government and public that Arafat was more likely to be untrustworthy than weak. By March 1996, even peace-seeking Israelis began to suspect that Arafat was unwilling rather than unable to pursue Hamas and, therefore, could not be trusted to fulfill the terms of a peace agreement. ${ }^{34}$

Second, by 1996 attempts to make peace with the Palestinians had become more costly than open conflict. Almost twice as many Israelis had been killed by terrorists by March 1996 than had been killed during the previous six years of conflict. Terrorist violence, therefore, had reduced the value Israelis placed on peace and elevated the level of trust Israelis required to continue negotiations with their opponent-an opponent they increasingly viewed as untrustworthy. According to

31. Newspaper headlines around the world announced "A Landslide Victory for Peace" and emphasized that the "Polls Strengthen Arafat's Grip on Power." See The Guardian [London], 23 January 1996, 12; and The Times, 23 January 1996, respectively.

32. Some argue that Hamas was motivated in these attacks by revenge for the Israeli assassination of "the engineer," a Palestinian bomb-making expert, and that, in general, reciprocity and revenge explain Israeli-Palestinian violence rather than the strategic logic we outline here. However, Goldstein and his colleagues use events data to show that in the Israeli-Palestinian relationship from 1991 to 1995 , Israel reciprocated Palestinian cooperation and conflict, whereas Palestine (defined as the PLO, the Palestinian Authority, Hamas, and other groups directing violence or cooperation toward Israel) did not reciprocate Israel's. Goldstein et al. 2000. Thus the general case for Palestinian retaliation is somewhat weak. In the specific case of the 1996 bombings, even if we grant that some of the motivation behind them was revenge, their effectiveness in lowering Israeli trust and hence affecting the elections is still accounted for by our approach, and not by more traditional repeated prisoners' dilemma models based on reciprocity.

33. Data from the Tami Steinmetz Center for Peach Research at Tel Aviv University, 1995-96.

34. A national poll taken in August 1996 by the Tami Steinmetz Center found that 57 percent of Israelis were dissatisfied with how the Palestinians were performing regarding security at this time. 


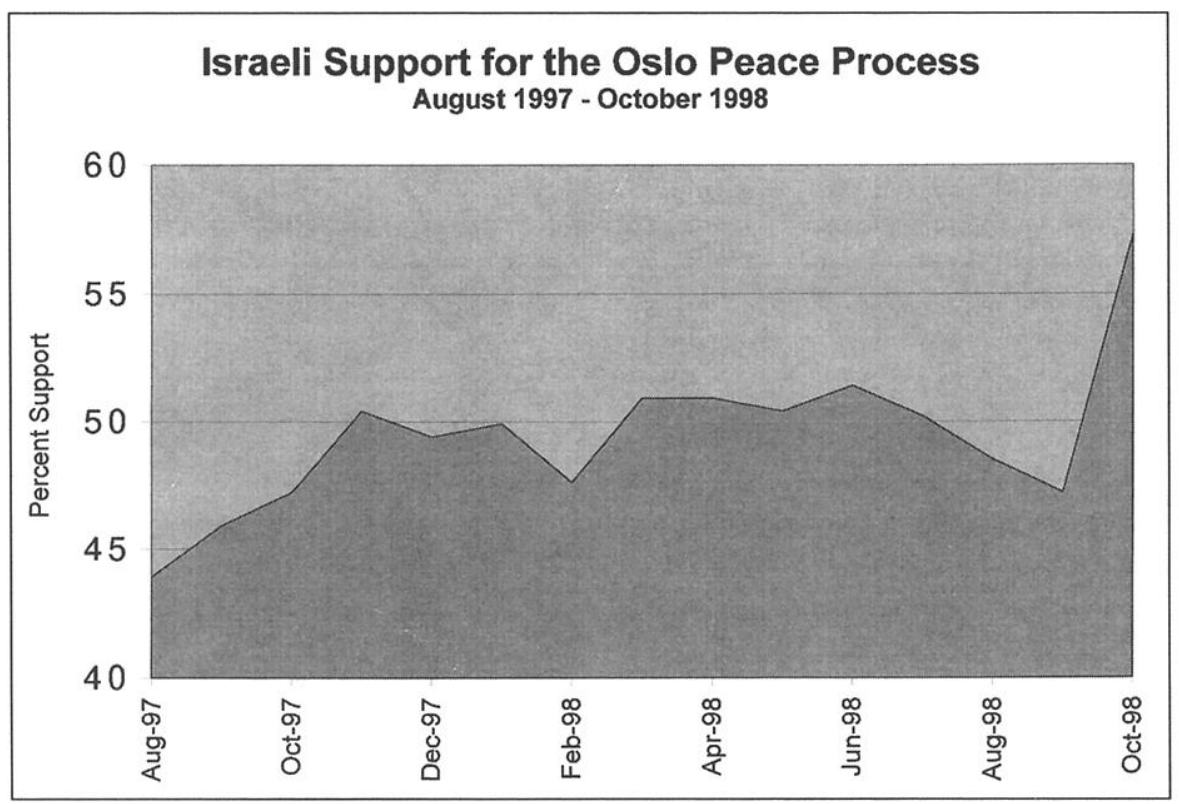

FIGURE 5. Israeli support for the Oslo peace process, August 1997-October 1998

hypothesis 2 (and 3a), this decreased value for peace helped enable extremist violence to succeed.

July-October 1998. Hamas did not launch another sustained attack on Israel until July 1998 when a flurry of diplomatic activity made it appear as if Netanyahu would break his negotiating freeze with the Palestinians. ${ }^{35}$ From July to October 1998 when the Wye accord was signed, Hamas launched ten attacks on Israel. This time, however, violence did not stop Netanyahu from pressing ahead with a land-for-peace deal with Arafat, and on 23 October 1998, the two men signed the Wye agreement. ${ }^{36}$

By 1998, three factors were working against Hamas. First, Arafat's increased efforts to thwart terrorist attacks as well as the significantly reduced number of attacks from May 1996 to July 1998 shifted public opinion in favor of once again pursuing peace with the Palestinians. As Figure 5 shows, Israeli support for the Oslo

35. The lack of violence during this time can also be partly attributed to greater efforts by the Palestinian Authority to prevent Hamas from carrying out terrorist attacks on Israel.

36. The Wye agreement set a detailed timetable for the Israelis to withdraw from an additional 13 percent of the West Bank, making Israeli withdrawal contingent on Palestinian compliance with weapons collection, arrest of suspects, and other security provisions. For additional details, see Morris 1999, 647. 
peace process rose from a low of 43.9 percent in August 1997 to a high of 57.3 percent in October 1998 when Wye was signed. ${ }^{37}$

Second, Netanyahu was forced to reopen meaningful talks with the Palestinian Authority after public opinion polls in October 1998 showed that a majority of Israelis supported the peace process and named Netanyahu as the primary reason for the lack of progress. ${ }^{38}$ Netanyahu, who enjoyed only a slim margin of victory in the 1996 elections, could not ignore public opinion, and when it became clear that the median voter supported negotiations, Netanhayu was forced to respond.

Third, the Wye accord included special provisions to reassure Israelis that the Palestinians would comply with the terms. Israeli would not be forced to withdraw from territory until the Palestinian Authority had fulfilled important security requirements, and the U.S. Central Intelligence Agency would serve to monitor and validate Palestinian performance on its promise to fight terrorism. This last provision would remove much of the uncertainty regarding Arafat's willingness to pursue Hamas and served to signal his true desire for peace. The result was to rebuild Israeli trust and reduce the effectiveness of any subsequent attacks.

Hamas's pre-election attack: November 2000-January 2001. There was little terrorist activity from October 1998 to December 2000 despite both the 1999 Israeli elections and the promising July 2000 Camp David negotiations. Hamas had every reason to remain quiet as Netanyahu struggled to win the election against a soft-line challenger; terrorist violence would only serve to further shift public opinion against Netanyahu and help elect the dovish Ehud Barak, something Hamas did not want to do. Hamas also had little incentive to launch attacks while the newly elected Barak pursued negotiations with Arafat since terrorist violence at this point was unlikely to change Barak's mind and halt negotiations. Barak had been elected on the promise to relaunch the Middle East peace process and forge a deal with Arafat, and the generous terms the Israeli prime minister offered during the July negotiations seemed to support this. Hamas had learned the lesson of the 1993 and 1994 bombing campaigns: terrorism would not prevent a determined dovish prime minister from pursuing peace. Hamas's next-best strategy was to target subsequent Israeli elections when the more hawkish and less trusting Likud party could be brought to power.

Hamas, therefore, remained quiet for almost two years and only launched a series of new attacks in the months preceding Israel's next election. The next wave of violence, which began in December 2000, had the desired effect. Barak lost the February 2001 elections by a landslide to the right-wing hard liner Ariel Sharon, and no serious negotiations have occurred since. ${ }^{39}$

37. Public support for the Oslo peace process was higher only in November 1995, in the weeks immediately following Rabin's assassination by a right-wing Israeli. See Steinmetz data.

38. Tami Steinmetz Center, from the first joint Israeli-Palestinian public opinion survey, October 1998.

39. This remains true as of November 2001. Our model predicts, however, that Hamas will resume attacks as soon as it appears that both Arafat and Sharon might renew peace talks. Terrorist attacks would 
Why was Hamas once again successful in achieving its goals? Two factors aided Hamas in its attempt to bring Sharon to power. First, trust in Arafat had significantly declined after he rejected what many people viewed as Barak's generous July terms. ${ }^{40}$ As one Israeli put it, "The truth is that I never really trusted Yasir Arafat. I think what happened was that when he faced the prospect of signing an agreement, he decided to run amok, like someone getting cold feet at a wedding."41

Second, Israelis continued to believe that Arafat was a strong leader and capable of halting violence at this time. Public opinion polls taken in February 2001 showed that the public believed Arafat was "in effect in full control" over what was happening on Palestinian streets. ${ }^{42}$ Yet the renewal of intifada-like violence and Arafat's willingness to release jailed members of Hamas, gave the appearance that the Palestinian Authority had no interest in preventing violence or pursuing peace. ${ }^{43}$ As violence increased, Israeli trust in the peaceful intentions of Arafat and the Palestinian Authority correspondingly declined. This low level of trust, together with the belief that Arafat had the ability to halt violence if he chose, set the stage for a successful campaign of violence by Hamas. The result was the election of a new hard-line government and an end to further progress toward peace.

Of course, Hamas cannot claim sole responsibility for the recent deterioration of relations between Israel and the Palestinian Authority nor for the election of Sharon. The renewal of the intifada in the wake of Sharon's October 2000 visit to the Temple Mount played a major role in diminishing Israeli trust in Arafat and support for the peace process. We do not claim, however, that the same strategy motivates both the intifada and Hamas. The intifada is best understood as a return to a war of attrition in the wake of a failed peace negotiation; both sides have returned to war in an attempt to wear down the other side and gain leverage for the next round of negotiations. What we do argue is that Hamas intentionally increased its attacks during this time in order to influence the outcome of Israel's February election and bring a more hard-line government to power. This was Hamas's best chance to prevent renewed negotiations.

Terrorist attacks that have occurred since the election might seem to be unexplained by our theory; with a hawkish prime minister and an intifada in full swing, attacks from Hamas might seem unnecessary. But this is not the case. There have been recurring efforts to negotiate ceasefires under Sharon, especially in the wake of the terrorist attacks on the United States on 11 September 2001. Our theory would

be particularly effective in scuttling additional negotiations at this point, given Sharon's already low level of trust.

40. Tami Steinmetz Center, Peace Index, July 2000.

41. Joel Greenberg, As Dreams of Peace Take Flight, Many Angry Fingers Point Toward Arafat, New York Times, 13 October 2000, A8.

42. Tami Steinmetz Peace Index, February 2001.

43. A survey taken by the Tami Steinmetz Center in October 2000 found "not only a decline in the confidence that peace had a chance in the foreseeable future, but also a loss of trust in the peaceful intentions of the Palestinians, as well as a growing belief in the strengthening of Yasir Arafat's terrorist image, and an erosion of his image as a statesman." 
strongly predict action from Hamas and other extremist groups to derail these efforts, and, indeed, at the time of this writing all such efforts have failed. In terms of our theory, as long as a hawkish Sharon faced a seemingly strong Arafat, attacks aimed at scuttling any attempts at peace would succeed.

\section{Conclusions}

The questions of what causes extremists to use violence and what accounts for the political effects of their attacks are pressing ones. We offer one possible explanation for why extremists sometimes succeed and sometimes fail in their efforts to sabotage peace negotiations and why moderate citizens who prefer peace return to war in response to provocation by a small group of rejectionists. We argue that terrorists are more likely to succeed in preventing peaceful compromise when mistrust is high, when the public and government are more hard line, and when the moderate opposition seems capable of preventing terrorist violence but fails to do so. Weak moderates may be forgiven for failing to prevent terrorist attacks, but strong moderates will not. This is the situation that appears to exist in Israel today.

Of course, mistrust is not the only reason why negotiations might fail. They also fail because combatants are unable to strike a mutually agreeable bargain, lack interest in settling, or cannot enforce the terms they do agree on. In addition, terrorists are not always the rational, calculating individuals we assume, and terrorist violence is certainly not always aimed at breaking down peace negotiations. Simple revenge or retaliation may explain some of the violence, and religious zeal may motivate individual terrorists, especially so-called suicide bombers who deliver some attacks. We believe, however, that the mechanisms our model highlights are crucial to explaining why terrorist violence sometimes succeeds in provoking a return to war, even among a larger population that would otherwise prefer peace.

Our model has direct implications for policymakers who wish to facilitate lasting peace settlements and to understand the strategies of terrorism. Outsiders might be able to help facilitate peace in cases where small groups of extremists are able to reignite a war despite signed peace treaties. If it is true that terrorism plays on the inherent uncertainty surrounding peace negotiations, then removing doubts about the intentions of moderates on both sides of the negotiating table will be key to deterring extremist violence and to neutralizing its negative effects. The model, therefore, suggests what moderates and interested international actors can do to reduce the influence of extremists. One of the most important tasks for moderates is to openly demonstrate the extent to which average citizens support the peace process. Public opinion polls can help, and even more convincing are referenda such as the one carried out in Northern Ireland for citizens to register support for the Belfast agreement. In this case, Catholics and Protestants overwhelmingly voted for peace, and the information provided by this highly public referendum helps to explain why terrorist violence subsequently declined and why attacks such as the Omagh bombing failed to undermine the peace process. 
International actors can also further the peace process by supplying credible information to both the target government and the average citizen about the opposition's intentions and its ability to suppress terrorists within its realm. The U.S. Central Intelligence Agency's participation in monitoring the activities of the Palestinian Authority toward Hamas in the aftermath of the Wye accord, for instance, provided an important source of information to the Israeli voter faced with additional terrorist attacks. ${ }^{44}$ By producing credible information about the opposition, outsiders can mitigate the uncertainty that allows terrorism to succeed and in so doing help deter additional attacks. Of course, information from outsiders is no panacea. It may be regarded as inadequate or biased, and it may be rejected. However, even a biased monitor could play an important role; moderates could choose to accept third-party monitors biased in favor of their opponent as a way to signal their sincere commitment to the terms of a treaty. Arafat's decision to accept CIA monitoring of the Wye agreement, for example, is likely to have been motivated at least in part by a desire to convince Israelis that the Palestinian Authority was earnest about stopping terrorism. The role of third-party information provision is an interesting avenue for future research.

Finally, our model also has direct implications for policymakers attempting to understand the motivations and strategies of terrorists in situations outside of peace processes. Our model suggests that extremists are likely to turn to terrorist violence in an attempt to discredit more moderate governments in the eyes of targeted populations. In the case of September 11, al Qaeda's attacks on the World Trade Center and the Pentagon could very likely have been designed to weaken the United States' trust of Arab governments in order to cause the United States to reduce support for these regimes and allow more radical Islamic regimes to take their place. ${ }^{45}$ Extremist violence in this case would play on the uncertainty the United States has regarding the trustworthiness of existing Arab regimes (such as the one currently in place in Saudi Arabia), and whether continued U.S. support of these regimes is justifiable or warranted. Exacerbating uncertainty and mistrust between

44. Why then do trustworthy moderates not welcome monitoring as a matter of course? While this may be a viable strategy under certain conditions, it comes at a cost. Moderates may worry that allowing external observers to monitor their efforts to crack down on extremists will reveal other information that they would prefer to keep secret. Examples include the names and whereabouts of their own underground agents, and the nature and location of the military capabilities moderates hold in reserve should the peace deal fall through. If information on these matters could be inadvertently revealed in the course of external observers monitoring the crackdown on extremists, moderates could feel that the risks of openness outweighed the gains. The more the moderate opposition trusted the external observer, presumably, the less it would fear that the third party would betray such secrets to the government. Unfortunately, a third party highly trusted by the moderate opposition might be less trusted by the government, leading the government to doubt the third party's word that the moderates were in fact cracking down. We do not focus on these dynamics and costs in the model; we simply assume that eliminating the uncertainty directly is not possible. However, it would certainly be worth exploring the implications of a more complex model in which alternative avenues for eliminating the uncertainty are available at various costs. These might provide reassurance even in the wake of successful terrorist attacks. We thank one of our reviewers for raising this issue.

45. See also Thomas Friedman, We Are All Alone, New York Times, 26 October 2001, A23. 
the United States and Arab governments, therefore, is one of the strategies al Qaeda has identified to achieve this goal.

\section{Appendix}

We focus on perfect Bayesian equilibria, which requires beliefs to be updated on the equilibrium path in accordance with Bayes's rule but does not restrict them off the equilibrium path. Given that moderates' choices are not directly observable, the only way to get observably off the equilibrium path is (1) for terrorism to occur in an equilibrium in which extremists do not attack or (2) for terrorism to not occur in an equilibrium in which extremists attack and no effort is made by strong moderates to suppress them. The second scenario is impossible in equilibrium because if no effort were made to stop extremists, terrorism would convey no information on the equilibrium path, so there would be no incentive to attack. In the first scenario we assume that if terrorism occurs when it is unexpected (that is, terrorists do not attack in equilibrium), the government's beliefs are updated as if the terrorists had been expected to attack and the strong trustworthy type of moderate had been expected to try to stop them, as in the separating equilibrium discussed later. This means that the government will become more suspicious of the moderates but not completely convinced that they are untrustworthy. The assumption is substantively motivated and eliminates some cases of multiple equilibria; similar results obtain with other reasonable assumptions, such as that beliefs do not change off the equilibrium path.

The payoff for fulfilling the deal for the soft-line government is $p_{\mathrm{MT}}\left(p_{\mathrm{MS}} P_{\mathrm{GS}}^{\mathrm{S}}+(1-\right.$ $\left.\left.p_{\mathrm{MS}}\right) P_{\mathrm{GS}}^{\mathrm{W}}\right)+\left(1-p_{\mathrm{MT}}\right) B_{\mathrm{GS}}$. The government will find it worthwhile to fulfill the deal if this beats the war payoff, which will be true if their level of trust exceeds the following critical value:

$$
p_{\mathrm{MT}}^{* \mathrm{~s}} \equiv \frac{W_{\mathrm{GS}}-B_{\mathrm{GS}}}{p_{\mathrm{MS}} P_{\mathrm{GS}}^{\mathrm{S}}+\left(1-p_{\mathrm{MS}}\right) P_{\mathrm{GS}}^{\mathrm{W}}-B_{\mathrm{GS}}} .
$$

For the hard-line government the critical value is:

$$
p_{\mathrm{MT}}^{* \mathrm{H}} \equiv \frac{W_{\mathrm{GH}}-B_{\mathrm{GH}}}{p_{\mathrm{MS}} P_{\mathrm{GH}}^{\mathrm{S}}+\left(1-p_{\mathrm{MS}}\right) P_{\mathrm{GH}}^{\mathrm{W}}-B_{\mathrm{GH}}} .
$$

Given that weak moderates pay a cost to suppress the extremists and have no chance of success, they will never attempt to suppress the extremists. The strong moderates may or may not suppress, leading to four possible patterns: (1) trustworthy strong moderates suppress, and untrustworthy strong moderates do not; (2) both trustworthy and untrustworthy strong moderates suppress; (3) trustworthy and untrustworthy strong moderates both do not suppress; and (4) trustworthy strong moderates do not suppress, and untrustworthy strong moderates do. We assume that the fourth possibility is ruled out by the payoffs of the moderates - that is, that untrustworthy moderates will never find it worthwhile to suppress if trustworthy moderates do not. The other three scenarios are considered below. 


\section{Case 1: Only Strong Trustworthy Moderates Suppress}

Here only the trustworthy strong moderates suppress, the other three types of moderates do not. To give the moderates the incentive to suppress, the extremist must attack in equilibrium. The reaction of the government depends on their type. The government's posterior probability that the moderates are trustworthy, given an attack, is given by Bayes's rule as follows:

$$
p_{\mathrm{MT}}^{\prime} \equiv \frac{p_{\mathrm{MT}}-q p_{\mathrm{MT}} p_{\mathrm{MS}}}{1-q p_{\mathrm{MT}} p_{\mathrm{MS}}}
$$

and the posterior belief that the moderates are strong is:

$$
p_{\mathrm{MS}}^{\prime} \equiv \frac{p_{\mathrm{MS}}-q p_{\mathrm{MT}} p_{\mathrm{MS}}}{1-q p_{\mathrm{MT}} P_{\mathrm{MS}}}
$$

To find when the government will become too suspicious to fulfill the deal in the wake of an attack, we can set the posterior beliefs equal to the critical value for the trust game identified earlier, $p_{\mathrm{MT}}^{\prime}=p_{\mathrm{MT}}^{* \mathrm{~S}}$, and $p_{\mathrm{MT}}^{\prime}=p_{\mathrm{MT}}^{* \mathrm{H}}$, and solve for the prior level of trust, $p_{\mathrm{MT}}$. Doing so yields two new critical values, one for the soft-line government:

$$
p_{\mathrm{MT}}^{* * \mathrm{~S}} \equiv \frac{p_{\mathrm{MT}}^{* \mathrm{~S}}}{1-q p_{\mathrm{MS}}+q p_{\mathrm{MS}} p_{\mathrm{MT}}^{* \mathrm{~S}}}
$$

and an analogous one for the hard-line government, denoted $p_{\mathrm{MT}}^{* * \mathrm{H}}$.

Now consider the extremists. They must attack whether the moderates are trustworthy or untrustworthy. In the first version of this equilibrium, attacking convinces both types of the government to reject the deal. Thus the payoff for attacking is $W_{\mathrm{E}}-t_{\mathrm{E}}$. Failing to attack convinces the government that the moderates are trustworthy and strong, so the government will accept the deal. If the moderates really are trustworthy, they will fulfill the deal, giving the extremists payoffs of $\boldsymbol{P}_{\mathrm{E}}$. If the moderates are untrustworthy, they will betray the deal, giving extremists payoffs of $B_{\mathrm{E}}$. Thus for the extremists to prefer to attack it must be the case that $W_{\mathrm{E}}-t_{\mathrm{E}}>\max \left\{P_{\mathrm{E}}, B_{\mathrm{E}}\right\}$. In the second version, only the hard-line government will reject the deal in response to a terrorist attack. If the moderates are untrustworthy, the payoff for attacking is then $p_{\mathrm{GS}} B_{\mathrm{E}}+\left(1-p_{\mathrm{GS}}\right) W_{\mathrm{E}}-t_{\mathrm{E}}$. This payoff must be bigger than that for not attacking, in this case $B_{\mathrm{E}}$. If the moderates are trustworthy, then the payoffs for attacking is $p_{\mathrm{GS}} P_{\mathrm{E}}+\left(1-p_{\mathrm{GS}}\right) W_{\mathrm{E}}-t_{\mathrm{E}}$. This payoff must be bigger than the payoff from not attacking, in this case $P_{\mathrm{E}}$.

Now, consider the first decision by the strong moderates, whether to suppress the extremists or not. In the first separating equilibrium, failure to suppress will result in a terrorist attack and a rejection of the deal by the government, giving $W_{\mathrm{MT}}-t_{\mathrm{MT}}$ for the trustworthy moderates and $W_{\mathrm{MU}}-t_{\mathrm{MU}}$ for the untrustworthy. The payoffs are the same if suppression fails, with an additional cost of suppression thrown in. If suppression succeeds, the government will fulfill the deal; trustworthy moderates will fulfill the accord and untrustworthy ones will not. Payoffs for attempting suppression are therefore $q P_{\mathrm{MT}}+(1-$ $q)\left(W_{\mathrm{MT}}-t_{\mathrm{MT}}\right)-s_{\mathrm{MT}}$ for the trustworthy moderates and $q B_{\mathrm{MU}}+(1-q)\left(W_{\mathrm{MU}}-\right.$ 
$\left.t_{\mathrm{MU}}\right)-s_{\mathrm{MU}}$ for the untrustworthy moderates. The trustworthy and untrustworthy moderates will both be simultaneously willing to play their equilibrium strategies if

$$
q P_{\mathrm{MT}}+(1-q)\left(W_{\mathrm{MT}}-t_{\mathrm{MT}}\right)-s_{\mathrm{MT}}>W_{\mathrm{MT}}-t_{\mathrm{MT}}
$$

and

$$
q B_{\mathrm{MU}}+(1-q)\left(W_{\mathrm{MU}}-t_{\mathrm{MU}}\right)-s_{\mathrm{MU}}<W_{\mathrm{MU}}-t_{\mathrm{MU}}
$$

In the second separating equilibrium, only the hard-line government reacts to an attack by rejecting the deal. The payoffs for attempting suppression for the trustworthy moderates are $q P_{\mathrm{MT}}+(1-q)\left[p_{\mathrm{GS}} P_{\mathrm{MT}}+\left(1-p_{\mathrm{GS}}\right) W_{\mathrm{MT}}-t_{\mathrm{MT}}\right]-s_{\mathrm{MT}}$ and for the untrustworthy $q B_{\mathrm{MU}}+(1-q)\left[p_{\mathrm{GS}} B_{\mathrm{MU}}+\left(1-p_{\mathrm{GS}}\right) W_{\mathrm{MU}}-t_{\mathrm{MU}}\right]-s_{\mathrm{MU}}$. The payoffs for not suppressing are $p_{\mathrm{GS}} P_{\mathrm{MT}}+\left(1-p_{\mathrm{GS}}\right) W_{\mathrm{MT}}-t_{\mathrm{MT}}$ and $p_{\mathrm{GS}} B_{\mathrm{MU}}+\left(1-p_{\mathrm{GS}}\right) W_{\mathrm{MU}}-t_{\mathrm{MU}}$ for the trustworthy and untrustworthy moderates, respectively. The equilibrium is possible when

$$
\begin{aligned}
q P_{\mathrm{MT}}+(1-q)\left(p_{\mathrm{GS}} P_{\mathrm{MT}}+\left(1-p_{\mathrm{GS}}\right) W_{\mathrm{MT}}-t_{\mathrm{MT}}\right) & -s_{\mathrm{MT}} \\
& >p_{\mathrm{GS}} P_{\mathrm{MT}}+\left(1-p_{\mathrm{GS}}\right) W_{\mathrm{MT}}-t_{\mathrm{MT}}
\end{aligned}
$$

and

$$
\begin{aligned}
q B_{\mathrm{MU}}+(1-q)\left(p_{\mathrm{GS}} B_{\mathrm{MU}}+\left(1-p_{\mathrm{GS}}\right) W_{\mathrm{MU}}-t_{\mathrm{MU}}\right) & -s_{\mathrm{MU}} \\
& <p_{\mathrm{GS}} B_{\mathrm{MU}}+\left(1-p_{\mathrm{GS}}\right) W_{\mathrm{MU}}-t_{\mathrm{MU}}
\end{aligned}
$$

\section{Case 2: Trustworthy and Untrustworthy Strong Moderates Suppress}

In the alternative class of separating equilibria, both trustworthy strong and untrustworthy strong moderates suppress the extremists, leaving only the weak moderates failing to suppress. The motivation on the part of the untrustworthy moderates is to attempt to trick the government into fulfilling the peace deal so that they can then betray it. In this type of separating equilibrium, a terrorist attack acts as a signal that the moderates are weak but provides no information about whether they are untrustworthy or trustworthy, since both untrustworthy and trustworthy moderates attempt to suppress.

In the second type of separating equilibrium, updating goes as follows. If there is no terrorist attack, the government knows that the moderates are strong for sure but has no new information about whether they are untrustworthy or trustworthy. Thus the posterior that they are strong is $p_{M S}^{\prime}=1$, whereas the posterior that they are trustworthy is the same as the prior, $p_{\mathrm{MT}}^{\prime}=p_{\mathrm{MT}}$. The soft-line government will then fulfill the deal if $p_{\mathrm{MT}}$ exceeds a critical value defined as follows:

$$
p_{\mathrm{MT}}^{\dagger \mathrm{S}} \equiv \frac{W_{\mathrm{GS}}-B_{\mathrm{GS}}}{P_{\mathrm{GS}}^{\mathrm{s}}-B_{\mathrm{GS}}}
$$


This is just a simplified version of $p_{\mathrm{MT}}^{* \mathrm{~S}}$, in the case where the value of peace is known to be the better one, because the moderates are known to be strong. A corresponding value for the hard-line government is $p_{\mathrm{MT}}^{\dagger \mathrm{H}}$.

If there is a terrorist attack, by contrast, the government becomes more suspicious that the moderates are weak. The posterior belief, $p_{\mathrm{MS}}^{\prime}$, can be derived from Bayes's rule and is as follows:

$$
p_{\mathrm{MS}}^{\prime} \equiv \frac{p_{\mathrm{MS}}-q p_{\mathrm{MS}}}{1-q p_{\mathrm{MS}}}
$$

Once again, however, the posterior level of trust, $p_{\mathrm{MT}}^{\prime}$, is equal to the prior $p_{\mathrm{MT}}$.

Substituting these posterior beliefs into the formula for $p_{\mathrm{MT}}^{* \mathrm{~S}}$ gives a critical value for the soft-line government of:

$$
p_{\mathrm{MT}}^{\dagger+\mathrm{S}} \equiv \frac{W_{\mathrm{GS}}-B_{\mathrm{GS}}}{\frac{p_{\mathrm{MS}}-q p_{\mathrm{MS}}}{1-q p_{\mathrm{MS}}} p_{\mathrm{GS}}^{\mathrm{s}}+\frac{1-p_{\mathrm{MS}}}{1-q p_{\mathrm{MS}}} p_{\mathrm{GS}}^{\mathrm{W}}-B_{\mathrm{GS}}}
$$

The soft-line government will fulfill the deal after a terrorist attack, if $p_{\mathrm{MT}}$ exceeds this value. A corresponding value for the hard-line type is denoted $p_{\mathrm{MT}}^{+\mathrm{H}}$. These critical values are greater than the first ones, that is, $p_{\mathrm{MT}}^{+\mathrm{S}}>p_{\mathrm{MT}}^{+\mathrm{S}}$, and $p_{\mathrm{MT}}^{+\mathrm{H}}>p_{\mathrm{MT}}^{+\mathrm{H}}$, because the effect of terrorism here is to convince the government that the value of peace is likely to be lower than anticipated, because the moderates are more likely to be weak. The boundary condition for the extremists is the same as for the previous separating equilibrium.

The boundary conditions for the moderate opposition are similar to the previous case, except that the second condition has the sign reversed so that the untrustworthy strong moderates are willing to make the attempt to suppress. For the first alternative separating equilibrium,

$$
q P_{\mathrm{MT}}+(1-q)\left(W_{\mathrm{MT}}-t_{\mathrm{MT}}\right)-s_{\mathrm{MT}}>W_{\mathrm{MT}}-t_{\mathrm{MT}}
$$

and

$$
q B_{\mathrm{MU}}+(1-q)\left(W_{\mathrm{MU}}-t_{\mathrm{MU}}\right)-s_{\mathrm{MU}}>W_{\mathrm{MU}}-t_{\mathrm{MU}} .
$$

For the second,

$$
\begin{aligned}
q P_{\mathrm{MT}}+(1-q)\left(p_{\mathrm{GS}} P_{\mathrm{MT}}+\left(1-p_{\mathrm{GS}}\right) W_{\mathrm{MT}}-t_{\mathrm{MT}}\right)- & s_{\mathrm{MT}} \\
& >p_{\mathrm{GS}} P_{\mathrm{MT}}+\left(1-p_{\mathrm{GS}}\right) W_{\mathrm{MT}}-t_{\mathrm{MT}}
\end{aligned}
$$

and

$$
\begin{aligned}
q B_{\mathrm{MU}}+(1-q)\left(p_{\mathrm{GS}} B_{\mathrm{MU}}+\left(1-p_{\mathrm{GS}}\right) W_{\mathrm{MU}}-t_{\mathrm{MU}}\right) & -s_{\mathrm{MU}} \\
& >p_{\mathrm{GS}} B_{\mathrm{MU}}+\left(1-p_{\mathrm{GS}}\right) W_{\mathrm{MU}}-t_{\mathrm{MU}}
\end{aligned}
$$


Anything that increases the costs the untrustworthy moderates pay to suppress the extremists, reduces the value of the betrayal outcome and increases the value of the war outcome, or lessens the cost to untrustworthy moderates of a terrorist attack makes this equilibrium less likely. Given the politics internal to the opposition, we feel that the cost for suppressing extremists will be higher for untrustworthy moderates, who will have preferences more closely aligned with those of the extremists, whereas the cost they feel from terrorism will be small, making this equilibrium unlikely in comparison to the separating equilibrium discussed in the article. The alternative separating equilibrium and the one discussed in the article are impossible for the same parameter values, so no problem of multiple equilibria arises here.

\section{Case 3: No Moderates Suppress}

For $p_{\mathrm{MT}}>p_{\mathrm{MT}}^{* * \mathrm{H}}$, there is a pooling equilibrium in which the terrorists do not attack, no type of moderate attempts to suppress them, and both types of government fulfill the deal regardless of whether there is a terrorist attack. There is also a pooling equilibria for $p_{\mathrm{MT}}<$ $p_{\mathrm{MT}}^{* \mathrm{~S}}$, where both types of government are so mistrustful of the moderates that they will not carry out the deal even if there is no terrorist attack. In this equilibrium, terrorists have no incentive to attack, since the government will reject the deal even without an attack, so the moderate opposition cannot signal by suppressing the extremists. In this region the first separating equilibrium is also possible, raising the issue of multiple equilibria. The extremists would prefer to coordinate expectations on the pooling equilibrium, because they get their highest payoff in it, whereas the strong trustworthy moderates would prefer to coordinate expectations on the separating equilibrium, because it gives them an opportunity to reassure the government. In general, however, this region of the parameter space is less interesting than is the case for higher levels of trust because agreements are unlikely to be signed if the existing level of trust is so low that the agreement is not expected to be carried out even in the absence of terrorist activity. In a more complicated model that includes the bargaining phase, this low trust zone would be the "no agreement" area.

\section{References}

Arian, Asher. 1995. Security Threatened: Surveying Israeli Opinion on Peace and War Cambridge: Cambridge University Press.

Bates, Robert H., Avner Grief, Margaret Levi, Jean-Laurent Rosenthal, and Barry R. Weingast. 1998. Analytic Narratives. Princeton, N.J.: Princeton University Press.

Cetinyan, Rupen, and Arthur A. Stein. 1997. Rational Extremism. Paper presented at the 93rd Annual Meeting of the American Political Science Association, Washington, D.C.

Coleman, James S. 1990. Foundations of Social Theory. Cambridge, Mass.: Belknap Press.

De Figueiredo, Rui, and Barry R. Weingast. 1998. Vicious Cycles: Endogenous Political Extremism and Political Violence. Unpublished manuscript, University of California, Berkeley.

Fearon, James D. 1998. Bargaining, Enforcement, and International Cooperation. International Organization 52 (2):269-305.

Fearon, James D., and David D. Laitin. 1996. Explaining Interethnic Cooperation. American Political Science Review 90 (4):715-35. 
Goldstein, Joshua A., Jon C. Pevehouse, Deborah J. Gerner, and Shibley Telhami. 2000. Reciprocity, Triangularity, and Cooperation in the Middle East, 1979-1997. Unpublished manuscript. Available at 〈www.american.edu/academic.depts/sis/goldtext/me98papr.htm).

Güth, Werner, and Hartmut Kliemt. 1994. Competition or Co-Operation: On the Evolutionary Economics of Trust, Exploitation, and Moral Attitudes. Metroeconomica 45 (2):155-87.

Kass, Ilana, and Bard O'Neill. 1997. The Deadly Embrace: The Impact of Israeli and Palestinian Rejectionism on the Peace Process. Lanham, Md.: University Press of America.

Kydd, Andrew. 2000. Trust, Reassurance, and Cooperation. International Organization 54 (2):325-57.

Mishal, Shaul, and Avraham Sela. 2000. The Palestinian Hamas: Vision, Violence, and Coexistence. New York: Columbia University Press.

Morris, Benny. 1999. Righteous Victims: A History of the Zionist-Arab Conflict, 188I-1999. New York: Alfred A. Knopf.

Morrow, James D. 1994. Game Theory for Political Scientists. Princeton: Princeton University Press.

Walter, Barbara F. 2002. Committing to Peace: The Successful Settlement of Civil Wars. Princeton, N.J.: Princeton University Press. 
http://www.jstor.org

\title{
LINKED CITATIONS
}

\author{
- Page 1 of 2 -
}

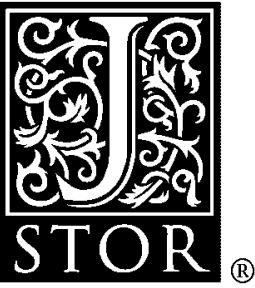

You have printed the following article:

Sabotaging the Peace: The Politics of Extremist Violence

Andrew Kydd; Barbara F. Walter

International Organization, Vol. 56, No. 2. (Spring, 2002), pp. 263-296.

Stable URL:

http://links.jstor.org/sici?sici=0020-8183\%28200221\%2956\%3A2\%3C263\%3ASTPTPO\%3E2.0.CO\%3B2-\%23

This article references the following linked citations. If you are trying to access articles from an off-campus location, you may be required to first logon via your library web site to access JSTOR. Please visit your library's website or contact a librarian to learn about options for remote access to JSTOR.

\section{[Footnotes]}

\author{
${ }^{6}$ Bargaining, Enforcement, and International Cooperation \\ James D. Fearon \\ International Organization, Vol. 52, No. 2. (Spring, 1998), pp. 269-305. \\ Stable URL: \\ http://links.jstor.org/sici?sici=0020-8183\%28199821\%2952\%3A2\%3C269\%3ABEAIC\%3E2.0.CO\%3B2-9

\section{${ }^{7}$ Explaining Interethnic Cooperation} \\ James D. Fearon; David D. Laitin \\ The American Political Science Review, Vol. 90, No. 4. (Dec., 1996), pp. 715-735. \\ Stable URL: \\ http://links.jstor.org/sici?sici=0003-0554\%28199612\%2990\%3A4\%3C715\%3AEIC\%3E2.0.CO\%3B2-8 \\ ${ }^{9}$ Trust, Reassurance, and Cooperation \\ Andrew Kydd \\ International Organization, Vol. 54, No. 2. (Spring, 2000), pp. 325-357. \\ Stable URL: \\ http://links.jstor.org/sici?sici=0020-8183\%28200021\%2954\%3A2\%3C325\%3ATRAC\%3E2.0.CO\%3B2-\%23
}

\section{References}

NOTE: The reference numbering from the original has been maintained in this citation list. 
http://www.jstor.org

\section{LINKED CITATIONS \\ - Page 2 of 2 -}

\section{Bargaining, Enforcement, and International Cooperation}

James D. Fearon

International Organization, Vol. 52, No. 2. (Spring, 1998), pp. 269-305.

Stable URL:

http://links.jstor.org/sici?sici=0020-8183\%28199821\%2952\%3A2\%3C269\%3ABEAIC\%3E2.0.CO\%3B2-9

\section{Explaining Interethnic Cooperation}

James D. Fearon; David D. Laitin

The American Political Science Review, Vol. 90, No. 4. (Dec., 1996), pp. 715-735.

Stable URL:

http://links.jstor.org/sici?sici=0003-0554\%28199612\%2990\%3A4\%3C715\%3AEIC\%3E2.0.CO\%3B2-8

Trust, Reassurance, and Cooperation

Andrew Kydd

International Organization, Vol. 54, No. 2. (Spring, 2000), pp. 325-357.

Stable URL:

http://links.jstor.org/sici?sici=0020-8183\%28200021\%2954\%3A2\%3C325\%3ATRAC\%3E2.0.CO\%3B2-\%23

NOTE: The reference numbering from the original has been maintained in this citation list. 